\title{
A multi-tracer approach to constraining artesian groundwater discharge into an alluvial aquifer
}

\author{
Charlotte P. Iverach ${ }^{1,2,3}$, Dioni I. Cendón ${ }^{1,2,3}$, Karina T. Meredith ${ }^{3}$, Klaus M. Wilcken ${ }^{3}$, Stuart I. Hankin ${ }^{3}$, \\ Martin S. Andersen ${ }^{1,4}$, and Bryce F. J. Kelly ${ }^{1,2}$ \\ ${ }^{1}$ Connected Waters Initiative Research Centre, UNSW Sydney, Sydney, NSW 2052, Australia \\ ${ }^{2}$ School of Biological, Earth and Environmental Sciences, UNSW Sydney, Sydney, NSW 2052, Australia \\ ${ }^{3}$ Australian Nuclear Science and Technology Organisation, New Illawarra Rd, Lucas Heights, \\ NSW 2234, Australia \\ ${ }^{4}$ School of Civil and Environmental Engineering, UNSW Sydney, Sydney, NSW 2052, Australia
}

Correspondence to: Bryce F. J. Kelly (bryce.kelly@unsw.edu.au)

Received: 8 June 2017 - Discussion started: 21 June 2017

Revised: 22 October 2017 - Accepted: 23 October 2017 - Published: 28 November 2017

\begin{abstract}
Understanding pathways of recharge to alluvial aquifers is important for maintaining sustainable access to groundwater resources. Water balance modelling is often used to proportion recharge components and guide sustainable groundwater allocations. However, it is not common practice to use hydrochemical evidence to inform and constrain these models. Here we compare geochemical versus water balance model estimates of artesian discharge into an alluvial aquifer, and demonstrate why multi-tracer geochemical analyses should be used as a critical component of water budget assessments. We selected a site in Australia where the Great Artesian Basin (GAB), the largest artesian basin in the world, discharges into the Lower Namoi Alluvium (LNA), an extensively modelled aquifer, to convey the utility of our approach. Water stable isotopes $\left(\delta^{18} \mathrm{O}\right.$ and $\left.\delta^{2} \mathrm{H}\right)$ and the concentrations of $\mathrm{Na}^{+}$and $\mathrm{HCO}_{3}^{-}$suggest a continuum of mixing in the alluvial aquifer between the GAB (artesian component) and surface recharge, whilst isotopic tracers $\left({ }^{3} \mathrm{H},{ }^{14} \mathrm{C}\right.$, and $\left.{ }^{36} \mathrm{Cl}\right)$ indicate that the alluvial groundwater is a mixture of groundwaters with residence times of $<70$ years and groundwater that is potentially hundreds of thousands of years old, which is consistent with that of the GAB. In addition, $\mathrm{Cl}^{-}$concentrations provide a means to calculate a percentage estimate of the artesian contribution to the alluvial groundwater. In some locations, an artesian contribution of up to $70 \%$ is evident from the geochemical analyses, a finding that contrasts with previous regional-scale water balance modelling estimates that attributed $22 \%$ of all inflow for the
\end{abstract}

corresponding zone within the LNA to GAB discharge. Our results show that hydrochemical investigations need to be undertaken as part of developing the conceptual framework of a catchment water balance model, as they can improve our understanding of recharge pathways and better constrain artesian discharge to an alluvial aquifer.

\section{Introduction}

Groundwater type mixing in an alluvial aquifer can occur between recently recharged groundwater (via infiltration from the land surface) and groundwater discharging into the alluvium from surrounding geological formations and artesian groundwater resources (Costelloe et al., 2012; Schilling et al., 2017; Rawling and Newton 2016; Salameh and Tarawneh, 2017). Insufficient spatial and temporal data resolution as well as heterogeneity in hydrogeological properties can result in considerable uncertainty when proportioning contributions from various sources in groundwater with mixed origins (Anderson and Woessner, 1992; Beven, 2009; Gardner et al., 2012). Additional uncertainties confounding source attribution include change in the magnitude of groundwater gradients and directions over time due to ongoing groundwater abstraction (for irrigation, stock, and domestic water supplies), and the impact that this and flood frequency may have on the extent of artesian discharge and groundwater mixing. These complexities make it challenging 
to accurately proportion contributions from various sources to an alluvial aquifer and to guide water allocations.

Water balance modelling of alluvial aquifers is commonly used to quantify and proportion recharge inputs from river leakage, floodwaters, areal (diffuse recharge), and discharge from artesian sources (Anderson and Woessner, 1992; Middlemis et al., 2000; Zhang et al., 2002; Dawes et al., 2004; Barnett et al., 2012; Giambastiani et al., 2012; Hocking and Kelly, 2016). Historically, hydrochemical analyses are not often used to constrain catchment-scale water balance modelling (Reilly and Harbaugh, 2004; Barnett et al., 2012), despite Scanlon et al. (2002) highlighting the need to use multiple techniques (including hydrochemical insights) to increase the reliability of recharge and discharge estimates. Geochemical data can improve our understanding of groundwater mixing processes because of the potential to trace pathways of groundwater movement and water-rock interactions, whilst also providing insights into the impacts of past groundwater extractions (Edmunds, 2009; Martinez et al., 2017). Therefore, the integration of geochemical evidence to constrain aquifer water balance models provides a more rigorous approach for proportioning input sources for groundwater that has mixed origins (Raiber et al., 2015; Currell et al., 2017).

Radioactive isotopic tracers that provide insights into groundwater residence times can constrain mechanisms of recharge and discharge, and detect groundwater mixing. Isotopes of dissolved species can be useful for elucidating groundwater mixing provided the different sources of groundwater have distinctly different and consistent isotopic signatures. However, each tracer has a different half-life and both physical and chemical processes and calculation assumptions can affect the interpretation of groundwater residence times (Jasechko, 2016). Therefore, multiple tracers are useful for covering the relevant timescales and uncertainties associated with the large range of groundwater residence times. Tritium $\left({ }^{3} \mathrm{H}\right)$ is an excellent indicator of modern recharge inputs in shallow groundwater (Robertson and Cherry, 1989; Chen et al., 2006; Duvert et al., 2016), and provides valuable information on processes active in the past $\sim 70$ years. Carbon-14 $\left({ }^{14} \mathrm{C}\right)$ is used to understand processes active from modern to $\sim 30 \mathrm{ka}$ (Clark and Fritz, 1997; Cartwright et al., 2010; Cendón et al., 2014) and chlorine-36 $\left({ }^{36} \mathrm{Cl}\right)$, whilst applicable in modern groundwater (Tosaki et al., 2007), is usually reserved for the identification of much older groundwater (100 ka to $1 \mathrm{Ma})$. One of the challenges of using ${ }^{36} \mathrm{Cl}$ is that, in certain cases, nucleogenic production of ${ }^{36} \mathrm{Cl}$ can be significant and/or varying $\mathrm{Cl}$ concentrations can complicate groundwater residence time interpretations. Additionally, the interpretation of ${ }^{36} \mathrm{Cl}$ can be affected by the input function, as ${ }^{36} \mathrm{Cl}$ values from rainfall vary temporally. This means that the input function for rainfall from any time in the past may be different from current conditions (Phillips, 2000). However, in regions with low and fairly consistent $\mathrm{Cl}$ concentrations (such as in our study area), ${ }^{36} \mathrm{Cl}$ values can provide solid indications of old groundwater residence times (Mahara et al., 2007).

These isotopes can also be used for tracer mixing calculations independent of residence time estimations (Bentley et al., 1986; Andrews and Fontes, 1993; Love et al., 2000; Moya et al., 2016). Therefore, the combination of ${ }^{3} \mathrm{H},{ }^{14} \mathrm{C}$, and ${ }^{36} \mathrm{Cl}$ dating techniques can provide hydrochemical process insights that cannot be captured by using only one isotope.

Identification of recharge and discharge pathways (particularly from underlying artesian contributions), and proportioning their relative contributions in a groundwater sample can be better constrained by combining traditional geochemical data with multiple dating techniques and other hydrologic analyses (Amiri et al., 2016; Rawling and Newton, 2016; Schilling et al., 2017). This is because groundwater geochemical data give insights into long-term patterns of mixing and groundwater flow, whereas other hydrologic data (such as hydraulic head differences) provide insights into seasonal pumping impacts, and current local and catchmentscale groundwater flow paths.

Here, we present for the first time a multi-tracer approach to constraining artesian discharge from the Great Artesian Basin (GAB) into the Lower Namoi Alluvium (LNA), northwest New South Wales (NSW), Australia (Fig. 1). We use water stable isotopes and major ion data to assess the major recharge and discharge pathways and occurrences of groundwater mixing in the LNA. We also use ${ }^{3} \mathrm{H},{ }^{14} \mathrm{C}$, and ${ }^{36} \mathrm{Cl}$ to show that artesian discharge from the underlying $\mathrm{GAB}$ to the LNA is locally much higher than is currently estimated from water balance models used to guide groundwater allocations in the region (Lower Namoi Groundwater, 2008). Our results highlight the need to consider a multi-tracer geochemical approach when assessing artesian contributions to alluvial aquifers and constraining water balance models of alluvial systems globally.

\section{Study area}

The Lower Namoi River catchment is located in the northwest of NSW, Australia (Fig. 1). Groundwater resources in the LNA are the most intensively developed in NSW (DPI Water, 2017). For this reason, there is concern regarding groundwater exploitation and threat to the long-term sustainability of the system (Lower Namoi Groundwater, 2008; DPI Water, 2017). Groundwater abstraction from the LNA supports a multibillion-dollar agricultural sector (focused around cotton growing established in the 1960s), supplying around $50 \%$ of water for irrigation in the region (Powell and Scott, 2011). Peak extraction of approximately $170 \times 10^{6} \mathrm{~m}^{3}$ occurred over the 1994-1995 growing season (Smithson, 2009). Consistently declining groundwater levels and concern regarding the long-term sustainability of groundwater abstraction led to the implementation of a water shar- 

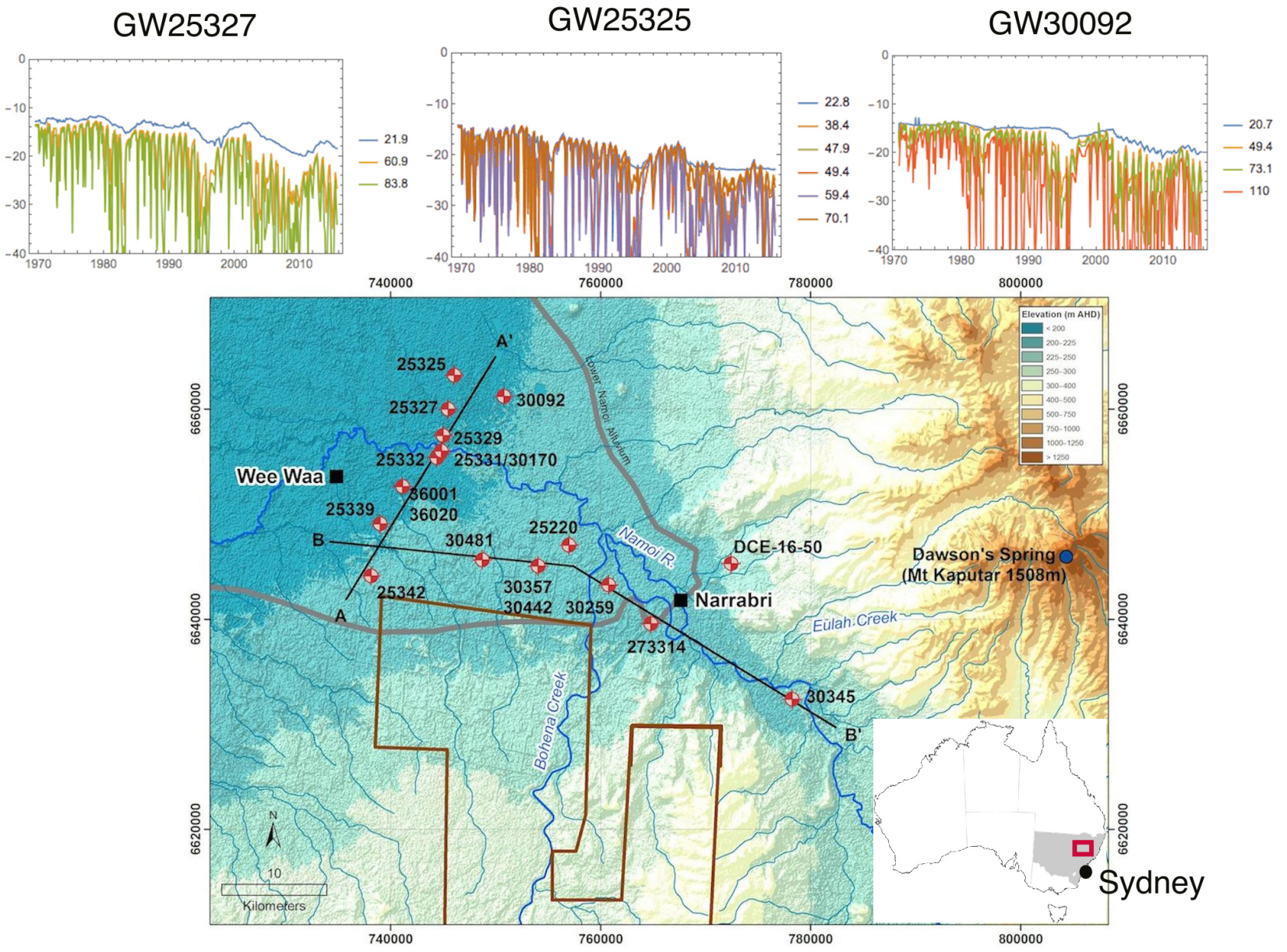

GW25332

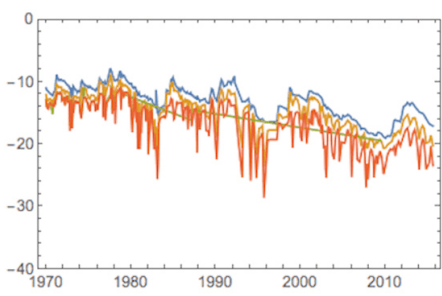

GW25339

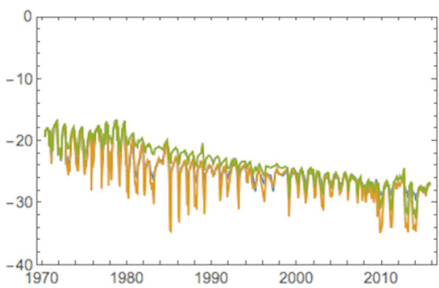

GW25342

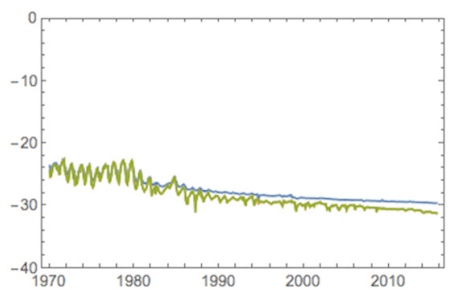

GW30481

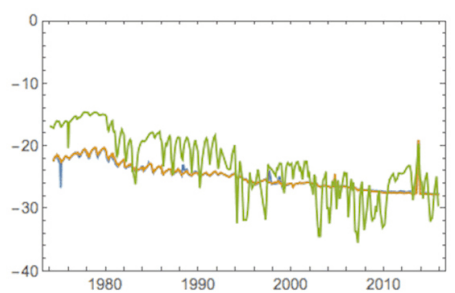

GW30259

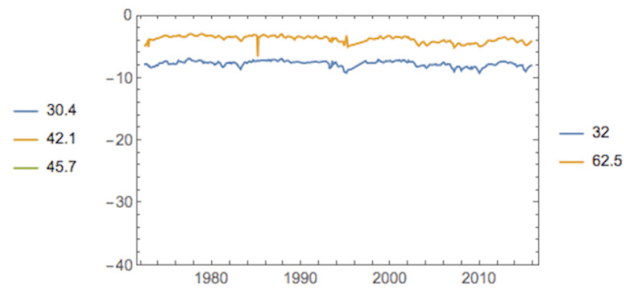

GW30345

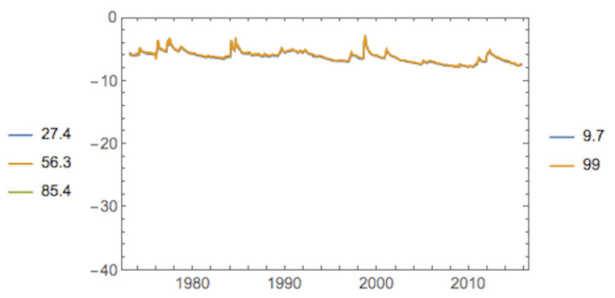

Figure 1. Map of the study area and sample locations, along with the location of the study area in Australia. Accompanying hydrographs show the groundwater level response in different piezometers throughout the study area (groundwater level data sourced from BOM, 2017). The different colours in the hydrographs represent the different monitoring bores in the nested set. The bottom of the slotted interval for each bore is shown in the key. The $x$ axis in each hydrograph is the year (1970-2010) and the $y$ axis is depth (between 0 and $40 \mathrm{~m}$ below ground surface, b.g.s.). The two locations with red text highlight areas where the hydrograph heads show clear GAB contribution, with the deeper piezometer showing a higher head than the shallow one. The remaining locations show no apparent GAB contribution to the LNA based on the hydrograph data. 
ing plan in 2006, which systematically reduced groundwater allocations to the irrigation sector over a 10 -year period. The present allocation is $86 \times 10^{6} \mathrm{~m}^{3}$ year $^{-1}$ (Lower Namoi Groundwater, 2008).

\subsection{Hydrogeological setting}

The Lower Namoi River catchment lies within the MurrayDarling Basin, overlying the Coonamble Embayment, which is in the south-east portion of the GAB (Radke et al., 2000). The southernmost portion of the LNA is underlain by Triassic formations, while north-west of monitoring bore 30345 the LNA is underlain by Jurassic formations (Fig. 2). Within the region of study, the oldest outcropping bedrock formation is the Early Triassic Digby Formation (lithic and quartz conglomerates, sandstones, and minor finer grained sediments; Tadros, 1993). The Digby Formation outcrops in the southeast of the area and the Namoi River abuts the formation just south of B' in Fig. 2. The Digby Formation is overlain by the Triassic Napperby Formation (thinly bedded claystone, siltstones, and sandstone). This formation occurs at a depth of $106 \mathrm{~m}$, just below the base of monitoring bore 30345 (NSW Pinneena Groundwater Database, driller logs). In outcrops to the east of the study area, the Napperby Formation is overlain by the Late Triassic Deriah Formation (green lithic sandstone rich in volcanic fragments and mud clasts; Tadros, 1993). The boundary between the Triassic and Jurassic lies west of monitoring bore 30345 . The Jurassic formations important to this study are the Purlawaugh Formation (carbonaceous claystone, siltstone, sandstone and subordinate coal), Pilliga Sandstone (medium to coarse quartzose sandstone) and the Orallo Formation (clayey to quartzose sandstone, subordinate siltstone and conglomerate; Tadros, 1993). The Pilliga Sandstone forms the bedrock below monitoring bores 25325 to 25342 , and in the Namoi region is the primary aquifer of the GAB.

From the Late Cretaceous to the mid-Miocene, a paleovalley was carved through the basement rocks (Kelly et al., 2014). Then from the mid-Miocene until present, the paleovalley was filled with reworked alluvial sediments. Groundwater abstraction in the study area is mostly from these alluvial sediments. Fluvial and aeolian interbedded clays, silts, sands, and gravels form the up to $\sim 140 \mathrm{~m}$ thick alluvial sequence of the Lower Namoi Catchment (Williams et al., 1989). Traditionally, three main non-formally defined aquifers/formations have been used to describe the LNA. The semi-confined Cubbaroo Formation overlies the bedrock in the northern paleochannel (which passes beneath monitoring bores 25325 and 30092). This formation is up to $60 \mathrm{~m}$ thick. The Cubbaroo Formation is overlain by the semi-confined Gunnedah Formation, which is up to $80 \mathrm{~m}$ thick, and is conformably overlain by the unconfined Narrabri Formation, which is 10 to $40 \mathrm{~m}$ thick (Williams et al., 1989). However, recent studies in the Namoi Catchment suggest that the rigid subdivision in to the Narrabri, Gunnedah, and Cubba- roo formations cannot easily explain the continuum in chemical evolution observed (discussed further below) and that the valley filling sequence is better characterised as a distributive fluvial system (Kelly et al., 2014; Acworth et al., 2015).

Groundwater drains from the Upper Namoi into the LNA via a bedrock constriction north of Narrabri and generally flows from east to west within the LNA (Barrett, 2012). Hydraulic conductivity in the alluvial aquifer is highly variable $\left(0.008-31 \mathrm{~m} \mathrm{day}^{-1}\right)$ due to the presence of variable sand and clay (Golder Associates, 2010). However, hydraulic conductivity generally increases with depth.

\subsection{Current understanding of recharge and discharge processes in the Lower Namoi Alluvium}

There have been numerous catchment water balance models and hydrochemical investigations in the study area because of the local and national economic importance of the LNA. However, the hydrochemistry of the groundwater in the region has not been used in conjunction with water balance modelling prior to this study (Merrick, 2000; CSIRO, 2007; Kelly et al., 2007).

\subsubsection{Water balance modelling of recharge}

To guide groundwater allocations from the LNA, a series of water budget models were developed using MODFLOW (Merrick, 2000; summarised in Kelly et al., 2007). These models were driven by climatic, rainfall, flood, and streamflow data and calibrated to groundwater head data. There are multiple plausible solutions for all water balance models and the solution presented is often constrained by several factors. These constraining factors include geological insights, the modeller's experience and biases (such as the way diffuse recharge is modelled either as a percentage of rainfall (Merrick, 2000; CSIRO, 2007) or as a complex evapotranspiration function (Giambastiani et al., 2012)), verification measures, and pragmatic goals. One MODFLOWderived water balance model proportioned the recharge for the water budget period 1980-1994 as the following: flood and diffuse rain recharge, $24.1 \times 10^{5} \mathrm{~m}^{3}$ year $^{-1}$; stream recharge, $33.7 \times 10^{5} \mathrm{~m}^{3}$ year $^{-1}$; up-gradient alluvial inflow, $3.06 \times 10^{5} \mathrm{~m}^{3}$ year $^{-1}$; and artesian (GAB) recharge, $9.5 \times 10^{5} \mathrm{~m}^{3}$ year $^{-1}$. In that model, artesian recharge was inferred to occur in the eastern portion of the model (between Narrabri and Wee Waa), which overlaps with this study area (Fig. 1). The zone between Narrabri and Wee Waa accounted for $42.7 \times 10^{5} \mathrm{~m}^{3}$ year $^{-1}$ of the total recharge to the LNA. Thus, according to the model, GAB discharge into the LNA in this area was equal to $22 \%$. When the LNA MODFLOW model was calibrated there was no consideration given to using hydrochemical data to constrain the calibration (Merrick, 2000; CSIRO, 2007; Kelly et al., 2007). 

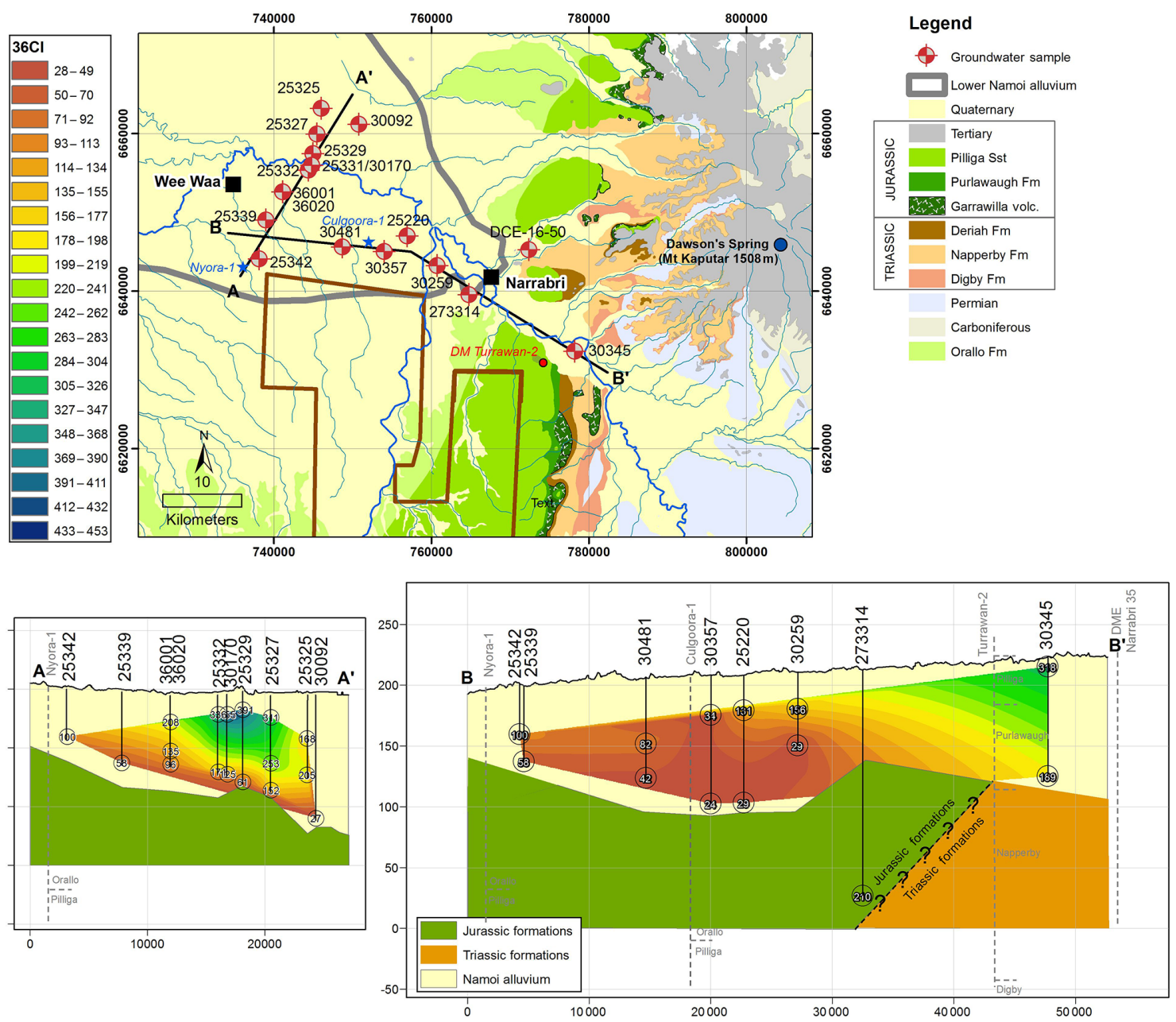

Figure 2. A geological map of the study area and two cross sections through the study area, showing the location and depth of the samples in the alluvium and their proximity to formations of the GAB. Contacts obtained from gas wells Nyora-1, Culgoora-1, and Turrawan-2, coinciding with our cross sections are added. Their locations are displayed on the map. The general direction of groundwater flow is from SE to NW, aligning with the B-B' line on the map. The ${ }^{36} \mathrm{Cl}$ data interpolated using the "natural neighbours" algorithm is shown in each cross section.

\subsubsection{Hydrochemical estimates of recharge}

The first isotopic investigation in the area was conducted from 1968 to 1975 and partially published by Calf (1978). The author used ${ }^{14} \mathrm{C}$ and ${ }^{3} \mathrm{H}$ to assess recharge pathways to the LNA and found evidence for river recharge in the upper aquifer, and that modern groundwater penetrated the deeper parts of the LNA. Calf (1978) also found evidence for "leakage" of groundwater from the GAB up into the deeper LNA; however, volumetric estimates were not provided.

McLean (2003) conducted an extensive hydrochemical and isotopic characterisation of both the GAB groundwater and the alluvial groundwater in 1999-2000. This research concluded that mixing of groundwater from the GAB into the lower and middle parts of the LNA is an important process especially in the south of the catchment. This study also did not quantify the amount of mixing occurring between the two groundwater sources.

The over-reliance of water balance models used to allocate groundwater resources that have not been constrained by isotopic tracer residence times or hydrochemical results is a common issue globally. This research highlights that hydrochemical investigations improve our conceptual understanding of recharge pathways and that such investigations should be applied to all important groundwater resource assessments to enable sustainable management. 


\section{Materials and methods}

\subsection{Groundwater collection}

This study comprised two field campaigns, the first one from 28 January to 8 February 2016 (summer) when the aquifer was stressed by pumping for irrigation, and the second from 21 June to 30 June 2016 (winter) in the absence of abstraction for irrigation.

In summer, 28 groundwater samples were collected from NSW Department of Primary Industries Water (DPI Water) monitoring bores and a surface water sample from the Namoi River. In winter, 16 groundwater samples were collected from NSW DPI Water monitoring bores and surface water samples from the Namoi River and two upstream tributaries (see Supplement Table S2 for locations). The bores were screened at varying intervals (average length of screened interval: $5.6 \mathrm{~m}$, see Table $\mathrm{S} 2$ for individual bores), intersecting the shallow, middle, and deep alluvium. Most bores were sampled with either a Grundfos (MP1 sampling pump) or Bennett compressed air piston pump, with the pump placed $\sim 1 \mathrm{~m}$ above the screen when using the Grundfos pump. Drop-tube extensions were used with the Bennett pump to place the pump intake just above the screen. Some deep monitoring bores were sampled with a portable bladder pump using low-flow methods (Puls and Barcelona, 1996). In these bores the pump was placed approximately $10 \mathrm{~m}$ below standing water level, with a drop tube cut to place the pump intake within the screen. For shallower bores (less than $50 \mathrm{~m}$ ), a $12 \mathrm{~V}$ battery operated pump was used with the pump intake placed $\sim 1 \mathrm{~m}$ above the screen. For all sample sites, physicochemical parameters ( $\mathrm{pH}, \mathrm{DO}, \mathrm{EC})$ were monitored and samples collected once three well volumes had been pumped and/or the physico-chemical parameters stabilised. This was generally achieved within 1 to $3 \mathrm{~h}$ after onset of pumping. Sample collection involved an in-line, $0.45 \mu \mathrm{m}$, high-volume filter connected to a high-density polyethylene (HDPE) tube. Total alkalinity concentrations (field alkalinity) were determined in the field by acid titration using a HACH digital titrator and external $\mathrm{pH}$ meter control. The $\mathrm{Fe}^{2+}$ and $\mathrm{HS}^{-}$ concentrations were determined using a portable colorimeter (HACH DR/890).

Samples for anion and water stable isotope $\left(\delta^{2} \mathrm{H}\right.$ and $\left.\delta^{18} \mathrm{O}\right)$ analyses were collected in 60 and $30 \mathrm{~mL}$ HDPE bottles respectively with no further treatment. Samples for cation analysis were collected in $60 \mathrm{~mL}$ HDPE bottles and acidified with ultrapure nitric acid. Samples for ${ }^{14} \mathrm{C}$ and ${ }^{3} \mathrm{H}$ were collected in $1 \mathrm{~L}$ narrow-mouth HDPE bottles and $2 \mathrm{~L}$ HDPE bottles respectively, and were sealed with tape to avoid potential atmospheric exchange during storage. Samples for ${ }^{36} \mathrm{Cl}$ were collected in $1 \mathrm{~L}$ narrow-mouth HDPE bottles with no further treatment. Major ion and ${ }^{14} \mathrm{C}$ samples were refrigerated at $4{ }^{\circ} \mathrm{C}$ until analysed.

We were not able to access any previously sampled GAB bores within the study area. Thus, to better constrain GAB groundwater characteristics, we used geochemical data from known GAB bores collected by Radke et al. (2000) and McLean (2003). These data were collected to the north-west of our study area and are used as a range (depending on availability of the original reported data) for the GAB endmember in our discussions (Table S1).

To help in the description of results, we use shallow $(<30 \mathrm{~m})$, intermediate $(30-80 \mathrm{~m})$, and deep $(>80 \mathrm{~m})$ as a rough guide to the origin of the groundwater sample. The chosen depth categories are based on clusters and trends in the ${ }^{14} \mathrm{C}$ analyses.

\subsection{Geochemical analyses}

Groundwater samples from both campaigns were analysed at ANSTO by inductively coupled plasma atomic emission spectroscopy (ICP-AES) for cations and ion chromatography (IC) for anions. Samples for $\delta^{2} \mathrm{H}$ and $\delta^{18} \mathrm{O}$ were analysed using cavity ring-down spectroscopy (CRDS) on a Picarro L2130- $i$ analyser. These values are reported as per mille deviations from the international standard V-SMOW (Vienna Standard Mean Ocean Water) and results have a precision of $\pm 1 \%$ o for $\delta^{2} \mathrm{H}$ and $\pm 0.15 \%$ or for $\delta^{18} \mathrm{O}$.

The ${ }^{14} \mathrm{C}$ samples were processed and analysed at ANSTO using methods described in Cendón et al. (2014). The ${ }^{14} \mathrm{C}$ activities were measured by accelerator mass spectrometry (AMS) using the ANSTO 2MV tandetron accelerator, STAR (Fink et al., 2004). The ${ }^{14} \mathrm{C}$ results were reported as percent modern carbon (pmc) following groundwater ${ }^{14} \mathrm{C}$ reporting criteria (Mook and van der Plicht, 1999; Plummer and Glynn, 2013) with an average $1 \sigma$ error of 0.21 pmc.

The ${ }^{3} \mathrm{H}$ samples were analysed at ANSTO. Water samples were distilled and electrolytically enriched prior to analysis by liquid scintillation. The ${ }^{3} \mathrm{H}$ concentrations were expressed in tritium units (TU) with a combined standard uncertainty of $\pm 0.03 \mathrm{TU}$ and quantification limit of $0.04 \mathrm{TU}$. Tritium was measured by counting beta decay in a liquid scintillation counter (LSC). A $10 \mathrm{~mL}$ sample aliquot was mixed with the scintillation cocktail that releases a photon when struck by a beta particle. Photomultiplier tubes in the counter convert the photons to electrical pulses that are counted over $51 \mathrm{cy}$ cles for $20 \mathrm{~min}$.

The ${ }^{36} \mathrm{Cl} / \mathrm{Cl}$ and ${ }^{36} \mathrm{Cl} /{ }^{37} \mathrm{Cl}$ ratios were measured by AMS using the ANSTO 6MV SIRIUS Tandem Accelerator (Wilcken et al., 2017). Samples were processed in batches of 10 , with each batch containing 1 chemistry blank. The amount of sample used was selected to yield $\sim 5 \mathrm{mg}$ of $\mathrm{Cl}$ for analysis without carrier addition. Chloride was recovered from the sample solutions by precipitation of $\mathrm{AgCl}$ from hot solution (Stone et al., 1996). This $\mathrm{AgCl}$ was redissolved in aqueous $\mathrm{NH}_{3}$ (20-22 wt \%, IQ grade, Seastar) to remove sulfur compounds of $\mathrm{Ag}$. Owing to isobaric interference of ${ }^{36} \mathrm{~S}$ with ${ }^{36} \mathrm{Cl}$ in the AMS measurements, a saturated $\mathrm{Ba}\left(\mathrm{NO}_{3}\right)_{2}$ solution $(99.999 \%$ trace metal basis) was used to precipitate sulfur as $\mathrm{BaSO}_{4}$. At least $72 \mathrm{~h}$ were allowed for 
$\mathrm{BaSO}_{4}$ to settle from a cold solution $\left(4{ }^{\circ} \mathrm{C}\right)$ in the dark before removal of the supernatant by pipetting and filtration (0.22 Millex GS). Pure $\mathrm{AgCl}$ was re-precipitated by acidifying the $\mathrm{Ag}\left(\mathrm{NH}_{3}\right)_{2}-\mathrm{Cl}$ solution with $5 \mathrm{M}$ nitric acid (IQ Seastar, sub-boiled). Finally, $\mathrm{AgCl}$ was recovered, washed twice, and dried. It was then pressed into high-purity $\mathrm{AgBr}$ (99\% trace metal basis, Aldrich) in $6 \mathrm{~mm}$ diameter $\mathrm{Cu}$ target holders. $\mathrm{AgBr}$ has a much lower sulfur content than $\mathrm{Cu}$. The stable $\mathrm{Cl}$ isotopes ${ }^{35} \mathrm{Cl}$ and ${ }^{37} \mathrm{Cl}$ were measured with Faraday cups, and ${ }^{36} \mathrm{Cl}$ events were counted with a multianode gas ionisation chamber. Gas (Ar) stripping (for good brightness/low-ion straggling) the ions to 5+ charge state in the accelerator terminal suffices for effective ${ }^{36} \mathrm{~S}$ interference separation in the ionisation chamber combined with sample-efficient and rapid analysis. Purdue PRIMELab Z930005 (nominally $1.20 \times 10^{-12}{ }^{36} \mathrm{Cl} / \mathrm{Cl}$ ) was used for normalisation with a secondary standard (nominally $5.0 \times 10^{-13}$ ${ }^{36} \mathrm{Cl} / \mathrm{Cl}$; Sharma et al., 1990) used for monitoring. Background subtraction was done with a linear dependence between ${ }^{36} \mathrm{Cl}$ rate and interfering ${ }^{36} \mathrm{~S}$ rate. This dependency is established by combining all the blank and test sample measurements and applied to the unknown samples during offline data analysis. This correction factor was typically less than analytical uncertainty of 3-4\% bar one sample that had a correction factor of $12 \%$ with an analytical uncertainty of $6 \%$.

\subsection{Geochemical calculations}

Calculations necessary to assess electrical neutrality, dissolved element speciation, and saturation indices for common mineral phases were undertaken using the PHREEQC Interactive program (3.3.8; Parkhurst and Appelo, 1999) and the incorporated WATEQ4F thermodynamic database (Ball and Nordstrom, 1991). The cation and anion analyses were assessed for accuracy by evaluating the charge balance error percentage $(\mathrm{CBE} \%)$. All samples fell within the acceptable $\pm 5 \%$ range, except for samples $25327-1(-7.8 \%)$ and 36001-1 $(-5.8 \%)$. The inverse geochemical modelling code NEPATH XL (Plummer et al., 1994; Parkhurst and Charlton, 2008) has been used to calculate the mixing ratio between two endmembers, using their $\mathrm{Cl}$ concentrations. The choice of endmembers will influence calculated proportions; however, endmembers were selected to provide conservative approximations.

Despite limitations, ${ }^{36} \mathrm{Cl}$ residence times for selected low ${ }^{36} \mathrm{Cl} / \mathrm{Cl}$ samples were calculated from the equations of Bentley et al. (1986). This allows a direct comparison, under similar assumptions, with other estimates obtained from GAB groundwater elsewhere (Bentley et al., 1986; Radke et al., 2000; Love et al., 2000; Moya et al., 2016) and within the Coonamble Embayment (Radke et al., 2000; Mahara et al., 2007). These calculations assume a piston flow setting with no other sources or sinks besides recharge and natural decay (Eq. 1):

$t=\frac{-1}{\lambda_{36}} \ln \frac{R-R_{\mathrm{se}}}{R_{0}-R_{\mathrm{se}}}$,

where $R$ is ${ }^{36} \mathrm{Cl} / \mathrm{Cl}$ ratio measured in the sample, $R_{0}$ is the initial ${ }^{36} \mathrm{Cl} / \mathrm{Cl}$ ratio (meteoric water), $R_{\mathrm{se}}$ is the ${ }^{36} \mathrm{Cl} / \mathrm{Cl}$ ratio under secular equilibrium (in this case the ${ }^{36} \mathrm{Cl} / \mathrm{Cl}$ ratio from the Pilliga Sandstone), and $\lambda_{36}$ is the decay constant $\left(2.303 \times 10^{-6}\right)$. We used a $R_{0}$ value of $160\left(\times 10^{-15}\right)$, which was an average of 10 samples compiled from studies in the Coonamble Embayment and reported in Radke et al. (2000). For $R_{\text {se }}$ a value of $5.7\left(\times 10^{-15}\right)$ was used, which is appropriate for aquifers dominated by sandstone (this secular equilibrium value can vary according to the dominant lithology). This $R_{\text {se }}$ value has been applied to ${ }^{36} \mathrm{Cl} / \mathrm{Cl}$ calculations elsewhere in the GAB (Moya et al., 2016) and is similar to that calculated from drill-core samples recovered in the GAB by Mahara et al. (2009).

\section{Results}

\subsection{Major ion chemistry}

The groundwater of the alluvial aquifer is predominantly $\mathrm{Na}-\mathrm{HCO}_{3}$-type water, with concentrations ranging from 0.12 to $54.6 \mathrm{mmol} \mathrm{L}^{-1}$ (average: $6.85 \mathrm{mmol} \mathrm{L}^{-1}$; SD: $8.7 \mathrm{mmol} \mathrm{L}^{-1}$ ) for $\mathrm{Na}^{+}$and 0.29 to $24.0 \mathrm{mmol} \mathrm{L}^{-1}$ (average: $6.43 \mathrm{mmol} \mathrm{L}^{-1}$; SD: $4.8 \mathrm{mmol} \mathrm{L}^{-1}$ ) for $\mathrm{HCO}_{3}^{-}$(Table S2). Generally, the highest concentrations of $\mathrm{Na}^{+}$and $\mathrm{HCO}_{3}^{-}$occur in the deeper groundwater and decrease up the vertical groundwater profile (Fig. 3a). The concentration of these two ions in the groundwater of the LNA is higher than expected from local rainfall sources and other shallow groundwater alluvial systems in eastern Australia (Martinez et al., 2017). In GAB groundwater, the $\mathrm{Na}: \mathrm{HCO}_{3}$ molar ratio is generally $1: 1$ and the two ions are generally present in higher concentrations than in our alluvial samples (Radke et al., 2000; McLean, 2003), which is evident in the position of the regional GAB samples in Fig. 3a.

Additional ions used in this study are $\mathrm{F}^{-}$and $\mathrm{Cl}^{-}$as well as the $\mathrm{Cl} / \mathrm{Br}$ ratio. The concentration of $\mathrm{F}^{-}$in the groundwater ranges from 0.002 to $0.215 \mathrm{mmol} \mathrm{L}^{-1}$ (average: $0.028 \mathrm{mmol} \mathrm{L}^{-1}$; SD: $0.04 \mathrm{mmol} \mathrm{L}^{-1}$ ). Fluoride concentrations generally increase with depth and accumulate in solution as all groundwater samples are below saturation with respect to fluorite (Fig. 3b). Concentrations of $\mathrm{Cl}^{-}$in the alluvial groundwater range from 0.063 to $26.73 \mathrm{mmol} \mathrm{L}^{-1}$ (average: $1.67 \mathrm{mmol} \mathrm{L}^{-1}$; SD: $3.7 \mathrm{mmol} \mathrm{L}^{-1}$ ). Unlike the other major ions, $\mathrm{Cl}^{-}$concentrations through the vertical groundwater profile are relatively stable (Fig. 3c). The relationship between $\mathrm{Cl}^{-}$and the $\mathrm{Cl} / \mathrm{Br}$ ratio shows that groundwater composition clusters from values below the seawater ratio to values close to seawater. The $\mathrm{Cl} / \mathrm{Br}$ ratios are similar to ranges found in other alluvial groundwater systems but 
slightly lower than ratios observed in other GAB samples for Australian locations (Herczeg et al., 1991; Cendón et al., 2010; Cartwright et al., 2010). Additionally, the $\mathrm{Cl} / \mathrm{Br}$ ratios in shallow samples connected to the river are consistent with expected ratios in rainfall (Short et al., 2017). The regional GAB samples (Radke et al., 2000) show a $\mathrm{Cl}$ / Br ratio more similar to seawater, with our samples from the LNA lying on a mixing trend between the two endmembers (Fig. 3c).

We identified one major outlier in the hydrochemical results, which was sample 273314. This sample is from $207 \mathrm{~m}$ b.g.s. and the bore screen is classified as being in the GAB. However, the geochemical parameters for this deep GAB sample have a signature more similar to river water than what would be expected in the GAB $207 \mathrm{mb}$ b.g.s. The concentration of $\mathrm{Na}^{+}, \mathrm{HCO}_{3}^{-}$, and $\mathrm{Cl}^{-}, \mathrm{F}^{-}$as well as the $\mathrm{Cl} / \mathrm{Br}$ ratio in this sample plot closer to the river and shallow groundwater than the deeper groundwater system (Fig. 3). Potential reasons for this are explored in detail below.

\subsection{Stable water isotopes $\left(\delta^{2} \mathrm{H}\right.$ and $\left.\delta^{18} \mathrm{O}\right)$}

The stable water isotopic values for this study range from -0.76 to $8.4 \%$ or $\delta^{18} \mathrm{O}$ and -7.5 to $-54.9 \%$ or for $\delta^{2} \mathrm{H}$. Most groundwater samples cluster together at around -6 and $-40 \%$ o $\left(\delta^{18} \mathrm{O}\right.$ and $\left.\delta^{2} \mathrm{H}\right)$ and lie on the global meteoric water line (GMWL), to the right of the nearest available local meteoric water lines (LMWL; Macquarie Marshes and Gunnedah; Fig. 4; Table S3). A group of mostly shallow samples collected from piezometers close to river channels define a trend to the right of the GMWL with a slope of 5.96, which is consistent with evaporation (Cendón et al., 2014). Our results are similar, including the shallow groundwater evaporative trend, to those recorded by McLean (2003). Water stable isotopic compositions for regional $\mathrm{GAB}$ samples range from -6.58 to $-6.24 \%$ for $\delta^{18} \mathrm{O}$ and -43.1 to $-38.8 \%$ ofor $\delta^{2} \mathrm{H}$ (McLean, 2003; Fig. 4).

\subsection{Isotopic tracers $\left({ }^{3} \mathrm{H},{ }^{14} \mathrm{C}\right.$, and $\left.{ }^{36} \mathrm{Cl}\right)$}

Tritium activities vary throughout the study area, ranging from below the quantification limit $(<0.04 \mathrm{TU})$ to $2.36 \mathrm{TU}$ (average: $0.42 \mathrm{TU}$ ). Tritium activities generally decrease with depth and distance from the river channel (Fig. 5; all data in Table S3). The highest ${ }^{3} \mathrm{H}$ activities of 2.31 and $2.36 \mathrm{TU}$ are from a sample $40 \mathrm{~m}$ from the river and the Namoi River itself respectively. These are very similar to modern rainfall in Australia ( 2-3 TU, Tadros et al., 2014), which suggests modern recharge near the river channels. However, ${ }^{3} \mathrm{H}>0.04 \mathrm{TU}$ was measured at depth (down to $207 \mathrm{~m}$ b.g.s.). The ${ }^{3} \mathrm{H}$ activities we measured at depth are significant for Australian groundwater, as the peak of the bomb pulse in Australia was only around $60 \mathrm{TU}$ compared to locations in the Northern Hemisphere. This is primarily because most thermonuclear testing was undertaken in the Northern Hemisphere far from Australia and mixing is limited between the atmospheric convection cells in the Northern and Southern hemispheres. Therefore, ${ }^{3} \mathrm{H}$ in Australian rainfall has been at natural background concentrations for some time (Tadros et al., 2014).

The ${ }^{14} \mathrm{C}$ content in the groundwater ranged from 0.2 to $107.6 \mathrm{pmc}$ (average: $54.0 \mathrm{pmc}$ ). Generally, groundwater samples shallower than $30 \mathrm{~m}$ had a high ${ }^{14} \mathrm{C}$ content $(>90 \mathrm{pmc})$, which decreased with depth. There were nine samples with a ${ }^{14} \mathrm{C}$ content below $1 \mathrm{pmc}$, indicating old groundwater (>30 ka), with total depths ranging from 35 to $207 \mathrm{~m}$ b.g.s.

Our ${ }^{36} \mathrm{Cl}$ results for the alluvial groundwater ranged from $24.06\left(\times 10^{-15}\right)$ to $455.35\left(\times 10^{-15}\right)$ (average: 169.4 $\left(\times 10^{-15}\right)$ (shown in the interpolation in Fig. 2). It has been found that groundwater in the $\mathrm{GAB}$ recharge zone closest to the study area has a ${ }^{36} \mathrm{Cl} / \mathrm{Cl}$ ratio up to $\sim 200\left(\times 10^{-15}\right)$ (Radke et al., 2000) with recharge values applied in calculations elsewhere in the GAB of $110\left(\times 10^{-15}\right)$ (Moya et al., 2016). Water from the Namoi River has a ${ }^{36} \mathrm{Cl} / \mathrm{Cl}$ ratio of $\sim 420\left(\times 10^{-15}\right)$ (Table S4).

\section{Discussion}

\subsection{Identification of recharge and mixing between the GAB and the LNA}

The $\delta^{18} \mathrm{O}$ and $\delta^{2} \mathrm{H}$ isotopic compositions suggest two mechanisms of recharge to the alluvium: artesian discharge and surface water infiltration. The regional GAB samples plot within the alluvial groundwater sample range, suggesting a $\mathrm{GAB}$ component in the alluvium. The evaporation line in Fig. 4 indicates recharge to the alluvium via surface water infiltration. It also shows a good connection between surface water that has undergone evaporation prior to recharge.

Additional evidence for these two mechanisms of recharge is the composition of $\mathrm{Na}^{+}$and $\mathrm{HCO}_{3}^{-}$in the LNA. Figure $3 \mathrm{a}$ shows a mixing line that the alluvial samples follow, plotting between the endmembers of the GAB and the Namoi River, suggesting an increasing $\mathrm{GAB}$ contribution to the alluvial groundwater with depth. This also implies that a continuum of mixing exists between the shallow and deep groundwater within the LNA. The shallow samples (25220-1 and 302591) that are more $\mathrm{Na}^{+}$enriched compared to samples from the GAB have undergone separate evapotranspiration processes and hence have a concurrent increase in $\mathrm{Cl}^{-}$. Assuming that $\mathrm{Cl}^{-}$is behaving conservatively (Appelo and Postma, 2005) we surmise that increases in dissolved major ion concentrations concomitant with increases in $\mathrm{Cl}^{-}$in the shallow groundwater are likely to be a result of evapoconcentration.

Further hydrochemical evidence for these recharge mechanisms is the covariation of $\mathrm{Na}^{+}$and $\mathrm{F}^{-}$, both interpreted as primarily derived from groundwater interaction with silicate minerals in this region (Airey et al., 1978; Herczeg et al., 1991; McLean, 2003; Fig. 3b). Our alluvial samples fall on the mixing line between samples from the river and nearby 

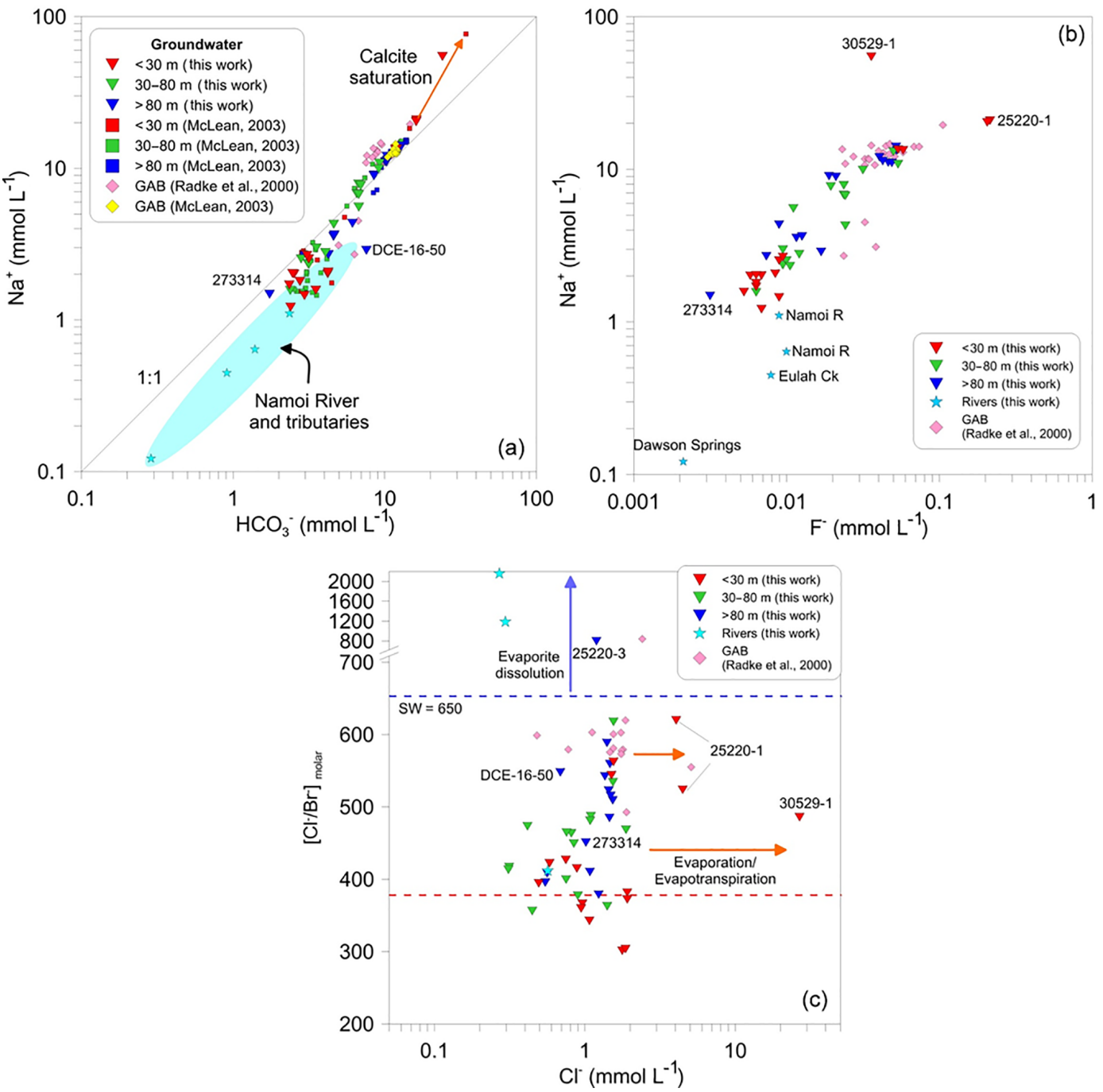

Figure 3. (a) $\mathrm{Na}^{+}$vs. $\mathrm{HCO}_{3}^{-}$showing the mixing trend that the alluvial samples form between the Namoi River and samples from the GAB (Radke et al., 2000; McLean, 2003). The orange calcite saturation line indicates samples that are more enriched due to separate evapotranspiration and calcite precipitation. The shaded blue ellipse represents all river chemistry data available for the Namoi River and tributaries (this work, $n=4$; McLean, 2003, $n=4$; Mawhinney, 2011, $n=79$ ). (b) $\mathrm{Na}^{+}$vs. $\mathrm{F}^{-}$and (c) $\mathrm{Cl}^{-} / \mathrm{Br}^{-}$vs. $\mathrm{Cl}^{-}$, highlighting the mixing trend between the surface recharge and the GAB that we observe in other geochemical indicators. The red dotted line represents the $\mathrm{Cl}^{-} / \mathrm{Br}^{-}$ratio for rainfall and the blue dotted line is the seawater ratio.

tributaries and regional samples from the GAB (Radke et al., 2000), in a similar way to the $\mathrm{Na}-\mathrm{HCO}_{3}$ trend that we observe in Fig. 3a. The $\mathrm{Cl} / \mathrm{Br}$ ratios in the groundwater also support the mixing interpretation provided by the $\mathrm{Na}^{+}$and $\mathrm{HCO}_{3}^{-}$concentrations, contrary to the possibility of waterrock interactions along the alluvium flow path (Fig. 3c). Furthermore, the relationship between ${ }^{36} \mathrm{Cl}$ and $\mathrm{Na}^{+}$provides additional evidence of mixing in the groundwater (Supplement Fig. S1).

Figure 3 also highlights the deep outlying sample (273314), which was 207 mb.g.s. in total depth, yet plots with the shallow alluvial and river samples. Figure 2 shows that this sample is situated just above the Napperby Forma- tion. We hypothesise that this sample originated from surface recharge from the Namoi River (which is in contact with the underlying Digby Formation to the south of the study area), with negligible input from the more $\mathrm{Na}-\mathrm{HCO}_{3}$-rich groundwater in the Pilliga Sandstone, where the sample is from. Sample 30345-2 (Tables S2 and S3), which is situated in the lower part of the LNA in proximity to the alluvial contact with the Napperby Formation (Fig. 2), has similar geochemistry. These results suggest the connection between deeper Triassic formations beneath the GAB and the Namoi River, which must be an important consideration in future water balance models of the catchment. 


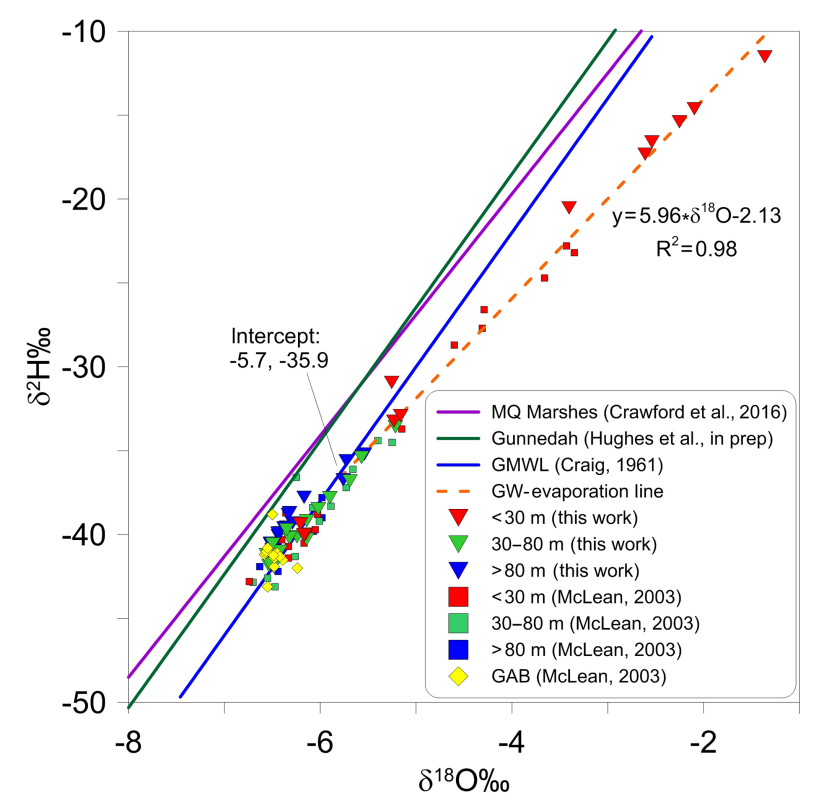

Figure 4. Water stable isotopes in the LNA, showing the two separate mechanisms of recharge; surface water recharge plotting along an evaporation trend line and potential inflow from the GAB clustered with regional samples from the GAB (McLean, 2003).

\section{Mixing between groundwaters of varying residence times}

Major ion and water stable isotope data suggest two primary mechanisms of recharge to the LNA and show that mixing is occurring within the alluvium. ${ }^{3} \mathrm{H}$ activity and ${ }^{14} \mathrm{C}$ content in the alluvial groundwater quantify the potential residence times of the groundwater sources that are mixing within the alluvium. Tritium activities $>0.04 \mathrm{TU}$ at depth (down to $207 \mathrm{~m}$ b.g.s.) indicate the extent of recharge from episodic flooding. Measuring ${ }^{3} \mathrm{H}>0.04 \mathrm{TU}$ at these depths also shows that surface recharge reaches the deeper LNA relatively quickly ( $<70$ years). Tritium data from the 1970 s collected from bores that were included in our sampling campaign (25329 and 25332; Calf, 1978) suggest that ${ }^{3} \mathrm{H}$ was already present in the deeper parts of the alluvial aquifer (>70 m b.g.s.) prior to a major flood in 1971, with activities ranging from 7.9 to $11.2 \mathrm{TU}$. This indicates good connectivity to and recharge from the surface. Additionally, measurements of ${ }^{3} \mathrm{H}$ in these bores post-flooding (16.6 to $20.7 \mathrm{TU}$ ) indicate that substantial recharge from the surface took place during this flood.

This highlights the importance of surface water recharge to the LNA. The activities of ${ }^{3} \mathrm{H}>0.04 \mathrm{TU}$ throughout the vertical profile of the LNA (Fig. 5) are inconsistent with the low ${ }^{14} \mathrm{C}$ contents in the groundwater. The presence of measurable ${ }^{3} \mathrm{H}$ but negligible ${ }^{14} \mathrm{C}$ (close to $0 \mathrm{pmc}$ ) suggests that mixing is occurring between groundwater that is associated with modern recharge processes in the alluvium and groundwater that,

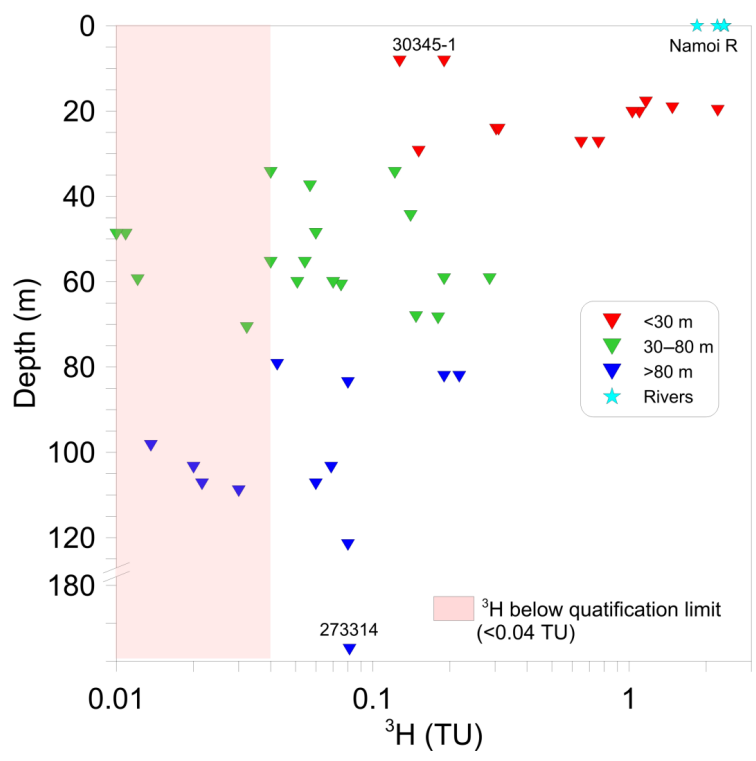

Figure 5. Plot of depth vs. ${ }^{3} \mathrm{H}$, highlighting the ${ }^{3} \mathrm{H}$ activity throughout the vertical groundwater profile. Samples that fall within the pink zone on the left are below the quantification limit $(<0.04 \mathrm{TU})$. These data are not included in our interpretation of how ${ }^{3} \mathrm{H}$ changes with depth. They are presented to convey the relative proportions of interpretable versus non-interpretable data.

as indicated by the ${ }^{14} \mathrm{C}$ content, is presumably much older. This older groundwater may be derived from artesian inflow. Figure 6 shows ${ }^{3} \mathrm{H}$ activities $>0.04 \mathrm{TU}$ in samples with ${ }^{14} \mathrm{C}$ content of almost $0 \mathrm{pmc}$, suggesting that groundwater with very low ${ }^{14} \mathrm{C}$ content is mixing with groundwater with high ${ }^{3} \mathrm{H}$ activity. Even though there is evidence of ${ }^{14} \mathrm{C}$ dilution in localised areas, we also observe mixing between groundwaters of widely different ${ }^{14} \mathrm{C}$ and ${ }^{3} \mathrm{H}$ values in the gradient of the samples in Fig. 6 (emphasised with a dotted blue line). This gradient would be steeper if there were mixing between groundwaters closer in residence times (Cartwright et al., 2013).

\subsection{Extent of interaction between the GAB and the LNA}

The ${ }^{3} \mathrm{H}$ and ${ }^{14} \mathrm{C}$ values show that there is mixing between groundwater of varying residence times; however, they provide little constraint on the groundwaters with a ${ }^{14} \mathrm{C}$ content of close to $0 \mathrm{pmc}$ (i.e. $>30 \mathrm{ka}$ ). This is where ${ }^{36} \mathrm{Cl}$ dating can be a useful tracer because it can be used to identify the presence of groundwaters that are much older than the range provided by ${ }^{14} \mathrm{C}$.

A plot of ${ }^{36} \mathrm{Cl} / \mathrm{Cl}$ vs. ${ }^{14} \mathrm{C}$ (in pmc; Fig. 7) shows a distinct mixing trend between groundwater with high and very low ${ }^{14} \mathrm{C}$ content. The two deep outlying samples (30345-2 and 273314; shaded yellow ellipse in Fig. 7) display different geochemical characteristics from the other samples, possibly because of their proximity to the Napperby Formation 


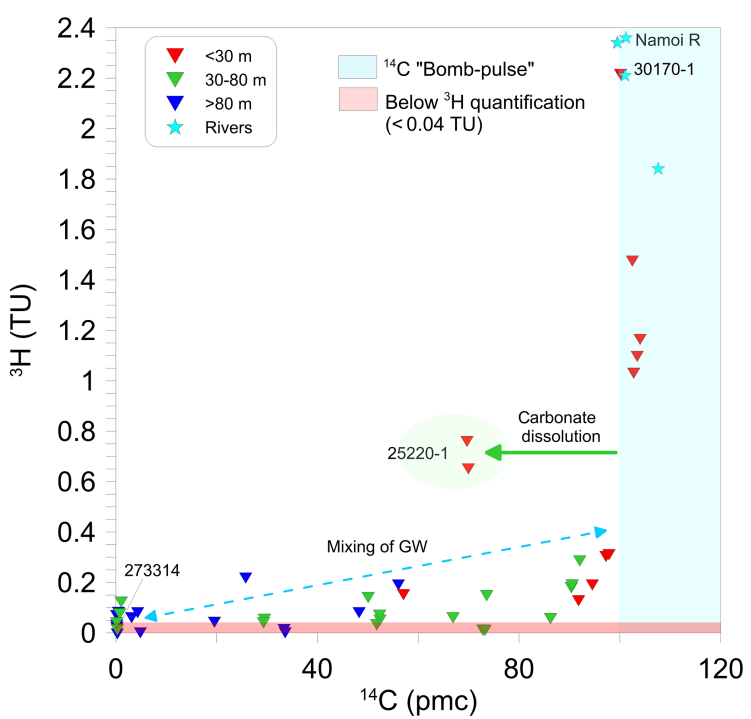

Figure 6. ${ }^{3} \mathrm{H}$ (TU) vs. ${ }^{14} \mathrm{C}$ (pmc). This shows the mixing between groundwater with quantifiable ${ }^{3} \mathrm{H}$ activity (as indicated by the red band) and groundwater with very low ${ }^{14} \mathrm{C}$ content (as indicated by the dotted blue line).

(Fig. 2). Figure 7 shows the ${ }^{36} \mathrm{Cl} / \mathrm{Cl}$ value range of $\mathrm{GAB}$ recharge, highlighting the alluvial samples with values lower than this GAB recharge value. Calculations suggest that these particular groundwater samples are potentially hundreds of thousands of years old, which is consistent with groundwater from the GAB. This implies that these alluvial groundwaters are influenced by artesian inflow of very old groundwater. This is evident in the natural neighbour interpolation in Fig. 2.

The apparent degree of ${ }^{36} \mathrm{Cl}$ decay observed in the alluvial groundwater samples is too large to be explained simply by radioactive decay as indicated by the measurable ${ }^{14} \mathrm{C}$ content in the same samples (Phillips, 2000). This means that the time needed for the ${ }^{36} \mathrm{Cl}$ to decay as much as observed would be well outside the range of ${ }^{14} \mathrm{C}$ dating (>30 ka) and therefore all groundwater samples would be expected to have ${ }^{a}{ }^{14} \mathrm{C}$ content of 0 pmc, which is not observed. Furthermore, the decrease in ${ }^{36} \mathrm{Cl}$ is unlikely to result from dilution by ${ }^{36} \mathrm{Cl}$-depleted sources such as evaporites, as the $\mathrm{Cl}^{-}$concentrations are similar in most samples (Fig. $8 \mathrm{a}$ and b). Therefore, mixing between groundwaters of different residence times is the most likely explanation for the observed ${ }^{36} \mathrm{Cl}$ signatures.

Our groundwater samples from the deep alluvium display lower ${ }^{36} \mathrm{Cl} / \mathrm{Cl}$ ratios (down to $24\left(\times 10^{-15}\right)$ ) than those measured in the GAB recharge zone. This indicates that there is very old groundwater in the deeper LNA (conceivably older than that of the GAB recharge zone), and that the mixing observed in our geochemical data could be taking place between groundwater with a residence time of less than 70 years (assumed using ${ }^{3} \mathrm{H}$ ) and groundwater with low ${ }^{36} \mathrm{Cl}$

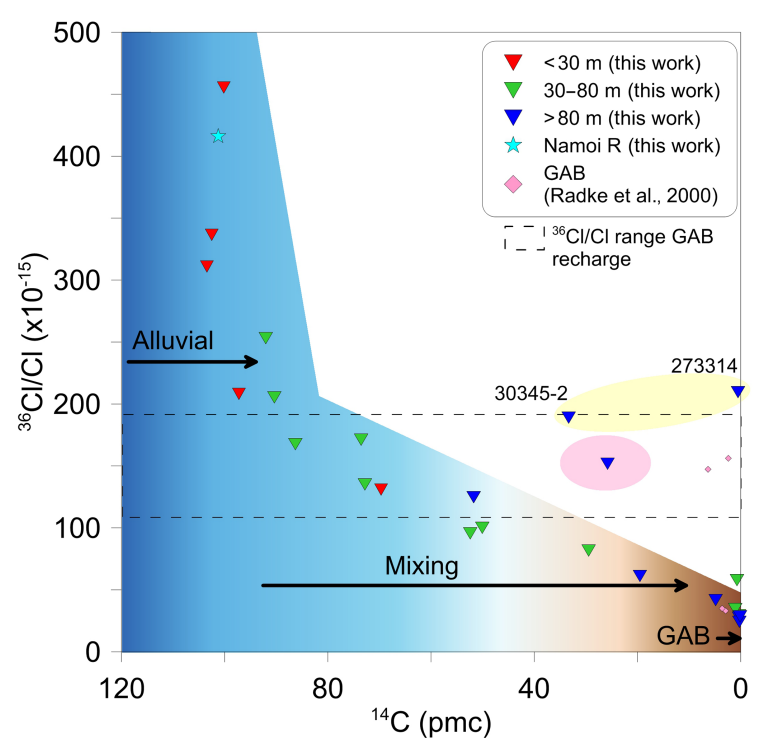

Figure 7. ${ }^{36} \mathrm{Cl} / \mathrm{Cl}\left(\times 10^{-15}\right)$ vs. ${ }^{14} \mathrm{C}(\mathrm{pmc})$. The colour gradient represents the mixing between the two major sources: surface water recharge (blue is modern) and the GAB (brown is old). The shaded yellow ellipse encompasses the two outliers where the geochemistry is being influenced by proximity to the Napperby Formation. The shaded pink ellipse is sample 25327-3, located in the irrigation area.

activities, consistent with GAB groundwater that is potentially hundreds of thousands of years old (Radke et al., 2000).

To quantify the extent of interaction between the two groundwater sources, we use the concentration of the conservative chloride ion to determine an approximate percentage of GAB to alluvial groundwater at each sample location. In general, $\mathrm{Cl}$ concentrations in surface water and shallow groundwater in the study area are low $\left(<30 \mathrm{mg} \mathrm{L}^{-1}\right)$, while samples recovered from the Pilliga Sandstone $(\mathrm{GAB})$ have higher concentrations $\left(\sim 60 \mathrm{mg} \mathrm{L}^{-1}\right)$. To estimate the local surface infiltration endmember, a shallow groundwater sample with high ${ }^{3} \mathrm{H}$ activity (sample 30170-1; $2.21 \mathrm{TU}$ ) was used. The average of all available GAB data was used for GAB inputs. These endmembers are mixed in varying proportions to obtain the $\mathrm{Cl}^{-}$concentration that we observe in all our groundwater samples (via inverse modelling calculations). If the $\mathrm{Cl}^{-}$concentration in the sample was lower than that in the representative local surface infiltration sample, a $100 \%$ LNA contribution is assumed. The representative sample used as the local surface infiltration endmember has been subject to some evaporation and therefore does not have the lowest $\mathrm{Cl}^{-}$concentration in the alluvium. If the sample with the lowest $\mathrm{Cl}^{-}$concentration was used as the surface water endmember, we would have required a higher percentage of GAB contribution across the study area. Thus, the use of the evaporated sample as our endmember represents a conservative approach when considering the mixing components from both the LNA and the GAB. 

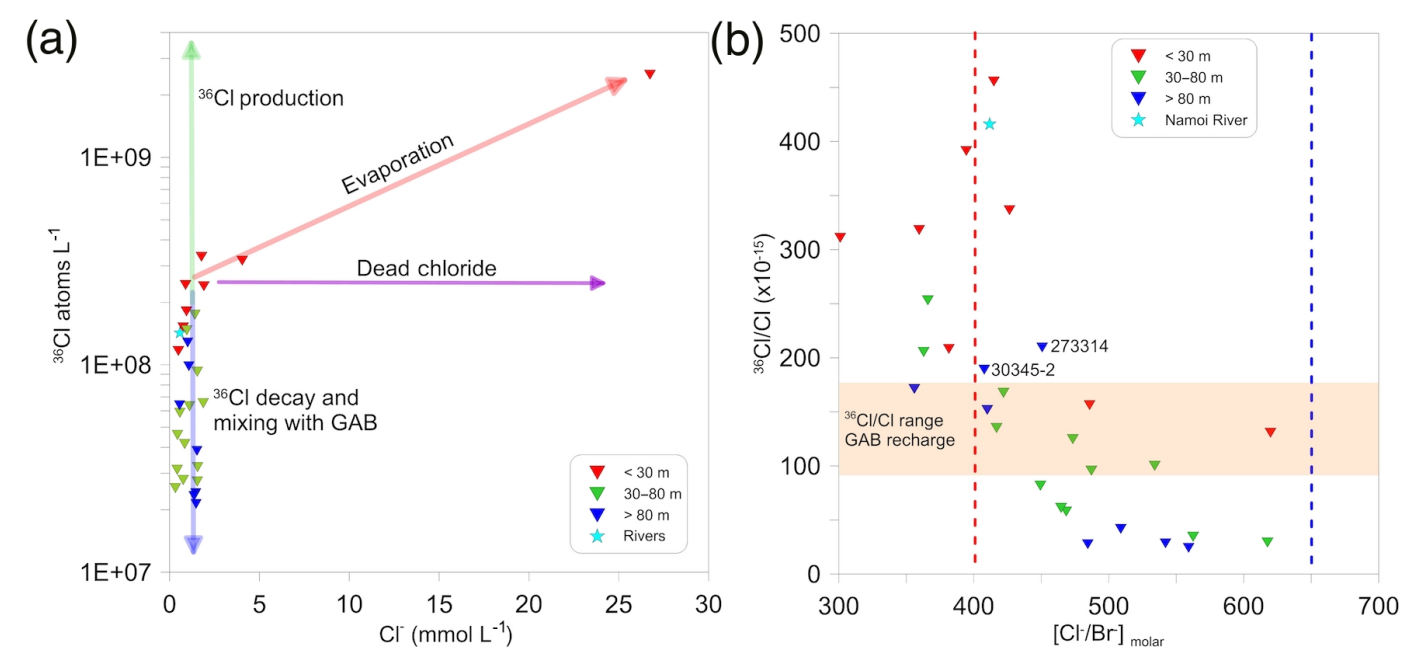

Figure 8. (a) ${ }^{36} \mathrm{Cl}$ vs. $\mathrm{Cl}^{-}$concentration. The ${ }^{36} \mathrm{Cl}$ production arrow represents potential in situ ${ }^{36} \mathrm{Cl}$ production from the high $\mathrm{U}$ and $\mathrm{Th}$ content in the host rocks. (b) ${ }^{36} \mathrm{Cl} / \mathrm{Cl}$ ratio $\left(\times 10^{-15}\right)$ vs. $\mathrm{Cl}^{-} / \mathrm{Br}^{-}$. The dotted blue line represents the $\mathrm{Cl}^{-} / \mathrm{Br}^{-}$ratio in seawater and the dotted red line represents the expected $\mathrm{Cl}^{-} / \mathrm{Br}^{-}$ratio for rainfall at Narrabri based on distance from the coast (Short et al., 2017).

The $\mathrm{Cl}$ mixing results provide an approximate mixing threshold with shallower samples generally containing a higher proportion of alluvial groundwater, which diminishes with depth. These mixing proportions show that some deeper samples in the LNA contain up to $70 \%$ GAB groundwater. Figure 9 presents approximate contours for artesian discharge proportions into the LNA based on the $\mathrm{Cl}$ mixing approach. The dotted lines indicate areas where there is just one sample to inform the interpretation, whereas the solid lines connect multiple samples that all displayed similar contributions from the GAB.

Artesian input can be inferred from nested piezometers at locations 30481 and 30259 (Fig. 1). At these locations, the monitoring bore slotted in the lower portion of the LNA has a head higher than the monitoring bore slotted in the shallow portion of the LNA, indicative of upward flow. At all other locations artesian contributions cannot be discerned from head data. Comparing Fig. 9 to Fig. 1, we show that groundwater geochemistry can provide a more accurate evaluation of GAB contribution to the LNA. This is because the geochemical data can elucidate groundwater mixing processes and provide longer-term insights compared to the hydraulic head data. Multiple geochemical tracers reveal that boreholes in the north and west of the study area may be experiencing much more GAB inflow than has been inferred in catchment water balance models (Merrick, 2000; Kelly et al., 2007; CSIRO, 2007). This is most evident at sample 25342. It is not immediately apparent from the vertical heads in the hydrograph set at sample 25342 that there is any GAB inflow, yet based on the geochemical tracers this location is $100 \%$ GAB groundwater. The water balance model described in Merrick (2000) has GAB groundwater contributing $22 \%$ of all inflow into the LNA between Narrabri and Wee Waa (Fig. 1). From the geochemistry alone it is not possible to make an estimate that can be directly compared to that artesian discharge estimate. However, it is apparent from the mixing results shown in Fig. 9 that a large portion of the study area has an artesian input to the LNA that is likely to be greater than $22 \%$. The above observations highlight why geochemical insights should ideally be used as one of the constraining data sets when doing water balance models in regions where there is both artesian discharge and surface water recharge to the alluvial aquifer.

\subsection{Temporal changes in the interaction between the LNA and the GAB}

The multiple geochemical tracers we have used show substantial artesian discharge to the LNA, which is larger than that currently considered in groundwater models of the region (Merrick, 2000; Kelly et al., 2007; CSIRO, 2007). However, it is difficult to constrain how the extent of artesian discharge has changed over time and how it may continue to change. Time series sampling can constrain how this GAB discharge will change and is important for understanding future artesian contributions to the LNA. Past ${ }^{14} \mathrm{C}$ (pmc) data collected from the same bores in 1978 (Calf), 2003 (McLean), 2010 (unpublished ANSTO data), and 2016 (this study) enable us to observe how the ${ }^{14} \mathrm{C}$ content in the groundwater has changed over time. The historical ${ }^{14} \mathrm{C}$ data, coupled with data from this study, have the potential to be used as a preliminary indicator of changes in the relative contributions of high ${ }^{14} \mathrm{C}$ contents from recent surface recharge $(\sim 100 \mathrm{pmc})$ versus low ${ }^{14} \mathrm{C}$ contents of the $\mathrm{GAB}$ discharge to the LNA. The data set contains 14 bores from five nested sites and is the most comprehensive long-term time series database for the study area, if not all of Australia, despite not being complete for all years. 


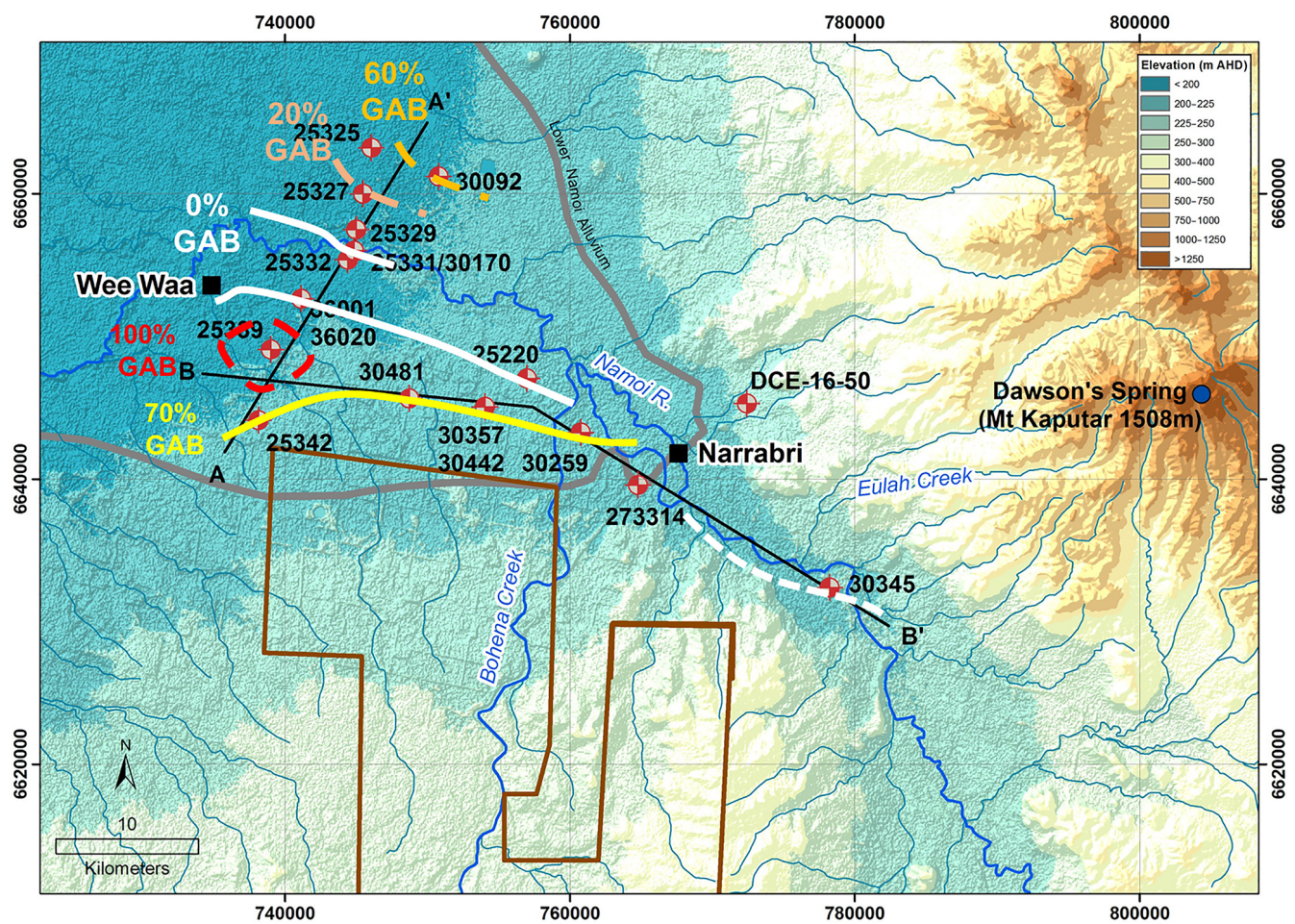

Figure 9. Approximate percentages of GAB contribution to the LNA, calculated from multiple geochemical tracers and major ion data.

Table 1. Changes in ${ }^{14} \mathrm{C}$ content (pmc) in select boreholes in the study area between 1978 and 2016 (see Figs. 1 and 8 for the locations of the bores). The five bores in bold text highlight where we observe changes in the ${ }^{14} \mathrm{C}$ content from 1978 to this study. Where available, the season and/or year of sampling is included. ND: no data.

\begin{tabular}{lrrrrrr}
\hline Bore & $\begin{array}{r}\text { Depth interval } \\
\text { (m b.g.s.) }\end{array}$ & $\begin{array}{r}\text { Calf } \\
(1978)\end{array}$ & $\begin{array}{r}\text { McLean } \\
(2003)\end{array}$ & $\begin{array}{r}\text { ANSTO data } \\
(\text { summer 2010) }\end{array}$ & $\begin{array}{r}\text { This study } \\
\text { (summer 2016) }\end{array}$ & $\begin{array}{r}\text { This study } \\
\text { (winter 2016) }\end{array}$ \\
\hline $\mathbf{2 5 2 2 0 / 1}$ & $\mathbf{2 4 . 4 - 3 0 . 5}$ & $\mathbf{2 8 . 1 5}$ & ND & ND & $\mathbf{6 9 . 6 6}$ & $\mathbf{6 9 . 9 4}$ \\
$25220 / 3$ & $97.5-109.7$ & 0.99 & ND & 0.13 & 0.17 & 0.22 \\
\hline $25325 / 2$ & $36.9-38.4$ & 83.63 & ND & 85.77 & 86.25 & ND \\
$\mathbf{2 5 3 2 5 / 6}$ & $\mathbf{6 7 . 1 - 7 0 . 1}$ & $\mathbf{6 5 . 3 1}$ & ND & $\mathbf{6 6 . 5 7}$ & $\mathbf{9 0 . 3 7}$ & ND \\
\hline $25332 / 1$ & $17.7-21$ & 103.61 & ND & ND & 102.48 & ND \\
$25332 / 2$ & $38.1-41.1$ & 99.19 & ND & 104.78 & ND & ND \\
$25332 / 3$ & $50.9-55.5$ & 94.70 & ND & ND & ND & ND \\
$\mathbf{2 5 3 3 2 / 4}$ & $\mathbf{6 6 . 8 - 6 9 . 8}$ & $\mathbf{4 9 . 3 3}$ & ND & $\mathbf{8 4 . 1 2}$ & $\mathbf{7 3 . 5 7}$ & ND \\
\hline $25327 / 1$ & $18.9-21.9$ & 123.36 & $101.3(\mathrm{~s})$ & ND & 103.43 & 102.74 \\
$25327 / 2$ & $57.9-60.9$ & 84.16 & $93.78(s)$ & ND & 92.05 & 90.56 \\
$\mathbf{2 5 3 2 7 / 3}$ & $\mathbf{8 0 . 8 - 8 3 . 8}$ & $\mathbf{8 . 4 8}$ & $\mathbf{8 . 6 3}(\mathbf{s})$ & ND & $\mathbf{2 5 . 7 9}$ & $\mathbf{5 6 . 0 8}$ \\
\hline $30092 / 1$ & $17.7-20.7$ & ND & $90.51(w)$ & ND & ND & ND \\
$\mathbf{3 0 0 9 2 / 2}$ & $\mathbf{4 8 . 2 - 4 9 . 4}$ & ND & $\mathbf{8 0 . 0 6}(\mathbf{w})$ & $\mathbf{7 2 . 3 1}$ & ND & $\mathbf{6 6 . 9 2}$ \\
$30092 / 4$ & $108.2-110$ & ND & $0.19(w)$ & 0.24 & 0.3 & 0.21 \\
\hline
\end{tabular}

Most of the samples displayed relatively consistent ${ }^{14} \mathrm{C}$ values across the years where data were available. However, we observed large changes in ${ }^{14} \mathrm{C}$ content in five monitoring bores; four showed an increase and one showed a decrease (bold text in Table 1). This suggests that the varying contri- butions of older and younger groundwater has changed over time, which could be a preliminary indicator of increased surface recharge to various sites, or increased artesian discharge to others. Therefore, measuring the ${ }^{14} \mathrm{C}$ in the groundwater at any future time and assessing how this has changed using 
past data is useful as a preliminary indicator for the current state of the system. However, consistent data collection and incorporation of other factors that may affect groundwater mixing (such as rate of groundwater extraction and amount of surface infiltration) are necessary to make inferences about temporal changes in the interaction between the LNA and the GAB.

\section{Conclusion}

We have used multiple geochemical tracers to show that artesian discharge to a shallow alluvial aquifer is higher than previously derived from water balance models in the literature (Merrick, 2000; CSIRO, 2007; Kelly et al., 2007). We have also provided a percentage estimate of GAB groundwater in each sample collected in the LNA using the concentration of $\mathrm{Cl}$ in the groundwater, showing that in some locations the "alluvial" sample is comprised of up to $70 \% \mathrm{GAB}$ groundwater. Our findings are important when considering the global importance of groundwater and the sustainable use of connected alluvial and artesian systems, globally.

Isotopic tracers $\left({ }^{3} \mathrm{H},{ }^{14} \mathrm{C}\right.$, and $\left.{ }^{36} \mathrm{Cl}\right)$ indicate that there is substantial mixing between two groundwater endmembers of very different residence times $(<70$ years and very old groundwater consistent with the GAB). This suggests interaction between modern surface recharge through the shallow LNA and variable artesian inflow at depth, dependent on where the sample is located in the system. We have also used past ${ }^{14} \mathrm{C}$ data $(1978,2003,2010)$, along with data from this study to show that these data can be used as a preliminary indicator of how the extent of interaction between the GAB and the LNA has changed over time. Yet, how these trends change geographically throughout the system and how they will behave in the future are difficult to constrain without continuous monitoring.

In the interval of the Lower Namoi studied discharge from the GAB into the LNA was previously considered to contribute approximately less than $22 \%$ of the input water to the LNA (Merrick, 2000; CSIRO, 2007; Kelly et al., 2007). However, the geochemical data reported above clearly indicate that GAB discharge is occurring in locations where inflow is not apparent from the nested hydrograph data. This highlights the need to apply multiple groundwater investigation techniques (including flow modelling, hydrograph analysis, geophysics, and geochemistry) when inferring artesian discharge to an alluvial aquifer. This research has demonstrated that a multi-tracer geochemical approach is required to better determine artesian contributions to the alluvial aquifer and must be considered in constraining future models of the study system and elsewhere.

Data availability. All data are provided in either the text itself or the Supplement.

\author{
The Supplement related to this article is available \\ online at https://doi.org/10.5194/hess-21-5953-2017- \\ supplement.
}

Author contributions. Experimental conceptualisation and design was carried out by DIC and BFJK. Fieldwork was conducted by CPI, DIC, SIH, and BFJK. Additional data was contributed by KTM. Geochemical analyses were conducted by CPI, DIC, and KMW. The manuscript was written by CPI with input from all authors.

Competing interests. The authors declare that they have no conflict of interest.

Acknowledgements. This research was funded by the Cotton Research and Development Corporation (CRDC). Charlotte Iverach was supported by scholarships from the Australian Government, ANSTO, and CRDC. ANSTO support and analytical staff are thanked for their continuous efforts (Chris Dimovski, Henri Wong, Robert Chisari, Vladimir Levchenko, Krista Simon, Alan Williams, Simon Varley). The authors also thank Lisa Williams for editing and proofreading the manuscript. In addition, many thanks to the associate editor (Markus Hrachowitz) and the three reviewers, who provided constructive feedback and raised the overall quality of the manuscript.

Edited by: Markus Hrachowitz

Reviewed by: three anonymous referees

\section{References}

Acworth, R. I., Timms, W. A., Kelly, B. F. J., McGeeney, D. E., Ralph, T. J., Larkin, Z. T., and Rau, G. C.: Late Cenozoic paleovalley fill sequence from the Southern Liverpool Plains, New South Wales - implications for groundwater resource evaluation, Aus. J. Earth. Sci., 62, 657-680, 2015.

Airey, P. L., Calf, G. E., Campbell, B. L., Hartley, P. E., Roman, D., and Habermehl, M. A.: Aspects of the isotope hydrology of the Great Artesian Basin, Australia, International Symposium on Isotope Hydrology, Germany, 1978.

Amiri, V., Nakhaei, M., Lak, R., and Kholghi, M.: Geophysical, isotopic, and hydrogeochemical tools to identify potential impacts on coastal groundwater resources from Urmia hypersaline Lake, NW Iran, Environ. Sci. Poll. Res., 23, 16738-16760, 2016.

Anderson, M. P. and Woessner, W. W.: Applied Groundwater Modelling: Simulation of Flow and Advective Transport, Academic Press, ISBN-10: 0-12-059485-4, London, 1992.

Andrews, J. N. and Fontes, J.-C.: Comment on "Chlorine 36 dating of very old groundwater, 3, Further results on the Great Artesian Basin, Australia” by T. Torgersen et al., Water Resour. Res., 296, 1871-1874, 1993.

Appelo, C. J. and Postma, D. (Eds.): Geochemistry, Groundwater and Pollution, 2nd Edition, Balkema, Rotterdam, https://doi.org/10.1201/9781439833544, 2005. 
Ball, J. W. and Nordstrom, D. K.: User's manual for WATEQ4F, with revised thermodynamic data base and text cases for calculating speciation of major, trace, and redox elements in natural waters, USGS Numbered Series Report, 91-183, 1991.

Barrett, C.: Upper Namoi groundwater source - status report 2011, NSW Department of Primary Industries, Office of Water, Sydney, 2012.

Barnett, B., Townley, L. R., Post, V., Evans, R. E., Hunt, R. J., Peeters, L., Richardson, S., Werner, A. D., Knapton, A., and Boronkay, A.: Australian groundwater modelling guidelines, Waterlines report, National Water Commission, Canberra, 2012.

Bentley, H. W., Phillips, F. M., Davis, S. N., Habermehl, M. A., Airey, P. L., Calf, G. E., Elmore, D., Gove, H. E., and Torgersen, T.: Chlorine 36 dating of very old groundwater. 1. The Great Artesian Basin, Australia, Water Resour. Res. 22, 1991-2001, 1986.

Beven, K.: Environmental Modelling: An Uncertain Future?, Routledge, ISBN-13: 978-0415457590, ISBN-10: 0415457599, Oxon, 2009.

Calf, G. E.: An investigation of recharge to the Namoi Valley aquifers using environmental isotopes, Aust. J. Soil Res., 16, 197-207, 1978.

Cartwright, I., Weaver, T., Cendón, D. I., and Swane, I.: Environmental isotopes as indicators of inter-aquifer mixing, Wimmera region, Murray Basin, Southeast Australia, Chem. Geol., 277, 214-226, 2010.

Cartwright, I., Fifield, L. K., and Morgenstern, U.: Using ${ }^{3} \mathrm{H}$ and ${ }^{14} \mathrm{C}$ to constrain the degree of closed-system dissolution of calcite in groundwater, Appl. Geochem., 32, 118-128, 2013.

Cendón, D. I., Larsen, J. R., Jones, B. G., Nanson, G. C., Rickleman, D., Hankin, S. I., Pyeyo, J. J., and Maroulis, J.: Freshwater recharge into a shallow saline groundwater system, Cooper Creek floodplain, Queensland, Australia, J. Hydrol., 392, 150163,2010

Cendón, D. I., Hankin, S. I., Williams, J. P., van der Ley, M., Peterson, M., Hughes, C. E., Meredith, K., Graham, I. T., Hollins, S. E., Levchenko, V., and Chisan, R.: Groundwater residence time in a dissected and weathered sandstone plateau: KulnuraMangrove Mountain aquifer, NSW, Australia, Aus. J. Earth Sci., 61, 475-499, 2014.

Chen, Z., Nie, Z., Zhang, G., Wan, L., and Shen, J.: Environmental isotopic study on the recharge and residence time of groundwater in the Heihe River Basin, northwestern China, Hydrogeol. J., 14, 1635-1651, 2006.

Clark, I. D. and Fritz, P. (Eds.): Age Dating Old Groundwater, Environmental Isotopes in Hydrogeology, CRC Press, USA, 1997.

Costelloe, J. F., Irvine, E. C., Weestern, A. W., and Tyler, M.: Identifying fluvial recharge and artesian upwards leakage contributions to arid zone shallow, unconfined groundwater, Chem. Geol., 326-327, 189-200, 2012.

CSIRO: Water availability in the Namoi, A report to the Australian Government from the CSIRO Murray-Darling Basin Sustainable Yields Project, CSIRO, Australia, 154 pp., 2007.

Currell, M. J., Werner, A. D., McGrath, C., Webb, J. A., and Berkman, M.: Problems with the application of hydrogeological science to regulation of Australian mining projects: Carmichael Mine and Doongmabulla Springs, J. Hydrol., 548, 674-682, 2017.
Dawes, W. R., Gilfedder, M., Walker, G. R., and Evans, W. R.: Biophysical modelling of catchment-scale surface water and groundwater response to land-use change, Math. Comp. Sim., 64, 3-12, 2004.

DPI Water: (Department of Primary Industries (DPI) Water): NSW Government, Namoi Alluvium Water Resource Plan (GW14), Status and Issues Paper, available at: http://www.water.nsw.gov.au/_data/assets/pdf_file/0020/ 701732/Status-and-Issues-Paper-Namoi-GW-WRP.pdf, last access: 6 June 2017.

Duvert, C., Stewart, M. K., Cendón, D. I., and Raiber, M.: Time series of tritium, stable isotopes and chloride reveal short-term variations in groundwater contribution to a stream, Hydrol. Earth Syst. Sci., 20, 257-277, https://doi.org/10.5194/hess-20257-2016, 2016.

Edmunds, W. M.: Geochemistry's vital contribution to solving water resource problems, Appl. Geochem., 24, 1058-1073, 2009.

Fink, D., Hotchkis, M., Hua, Q., Jacobsen, G., Smith, A. M., Zoppi, U., Child, D., Mifsud, C., van der Gaast, H., Williams, A., and Williams, M.: The ANTARES AMS facility at ANSTO, Nucl. Instrum. Meth. B, 223-224, 109-115, 2004.

Gardner, W. P., Harrington, G. A., and Smerdon, B. D.: Using excess ${ }^{4} \mathrm{He}$ to quantify variability in aquitard leakage, J. Hydrol., 468-469, 63-75, 2012.

Giambastiani, B. M. S., McCallum, A. M., Andersen, M. S., Kelly, B. F. J., and Acworth, R. I.: Understanding groundwater processes by representing aquifer heterogeneity in the Maules Creek Catchment, Namoi Valley (New South Wales, Australia), Hydrogeol. J., 20, 1027-1044, 2012.

Golder Associates Santos Gunnedah Basin CSG Project: Groundwater impact study - Kahlua pilot test, Report No. 107626100005-Rev1, Golder Associates, Australia, 2010.

Herczeg, A. L., Torgersen, T., Chivas, A. R., and Havermehl, M. A.: Geochemistry of ground waters from the Great Artesian Basin, Australia, J. Hydrol., 126, 225-245, 1991.

Hocking, M. and Kelly, B. F. J.: Groundwater recharge and time lag measurement through Vertosols using impulse response functions, J. Hydrol., 535, 22-35, 2016.

Jasechko, S.: Partitioning young and old groundwater with geochemical tracers, Chem. Geol., 427, 35-42, 2016.

Kelly, B. F. J., Merrick, N., Dent, B., Milne-Home, W., and Yates, D.: Groundwater Knowledge and Gaps in the Namoi Catchment Management Area, Cotton Catchment Communities CRC, University of Technology, Sydney - National Centre for Groundwater Management Report, NCGM 2007/1, 70 pp., 2007.

Kelly, B. F. J., Timms, W., Ralph, T. J., Giambastiani, B. M. S., Communian, A., McCallum, A. M., Andersen, M. S., Blakers, R. S., Acworth, R. I., and Baker, A.: A reassessment of the Lower Namoi Catchment aquifer architecture and hydraulic connectivity with reference to climate drivers, Aus. J. Earth Sci., 61, 501$511,2014$.

Lower Namoi Groundwater: NSW Government Department of Water and Energy, DWE_08_011, available at: http://www.water.nsw.gov.au/water-management/water-sharing/ plans_commenced/water-source/upper-lower-namoi-gw (last access: 20 September 2017), 2008.

Love, A. J., Herczeg, A. L., Sampson, L., Cresswell, R. G., and Fifield, L. K.: Sources of chloride and implications for $36 \mathrm{Cl}$ dat- 
ing of old groundwater, southwestern Great Artesian Basin, Australia, Water Resour. Res., 36, 1561-1574, 2000.

Mahara, Y., Habermehl, M. A., Miyakawa, K., Shimada, J., and Mizuochi, Y.: Can the $4 \mathrm{He}$ clock be calibrated by $36 \mathrm{Cl}$ for groundwater dating?, Nucl. Instrum. Meth. B, 259, 536-546, 2007.

Mahara, Y., Habermahl, M. A., Hasegawa, T., Nakata, K., Ransley, T. R., Hatano, T., Mizuochi, Y., Kobayashi, H., Nimomiya, A., Senior, B. R., Yasuda, H., and Obta, T.: Groundwater dating by estimation of groundwater flow velocity and dissolved $4 \mathrm{He}$ accumulation rate calibrated by $36 \mathrm{Cl}$ in the Great Artesian Basin, Australia, Earth Planet. Sci. Lett., 287, 43-56, 2009.

Martinez, J. L., Raiber, M., and Cendón, D. I.: Using 3D geological modelling and geochemical mixing models to characterise alluvial aquifer recharge sources in the upper Condamine River catchment, Queensland, Australia, Sci. Tot. Environ., 574, 1-18, 2017.

Mawhinney, W.: Namoi Water Quality Project 2002-2007 - Final report, NSW Office of Water, Sydney, 39 pp., available at: http://pandora.nla.gov.au/pan/126486/20110413-1101/ namoiwater.pdf (last access: 20 September 2017), 2011.

McLean, W. A.: Hydrogeochemical evolution and variability in a stressed alluvial aquifer system: Lower Namoi River catchment, NSW, PhD thesis, University of New South Wales, Sydney (unpublished), 2003.

Merrick, N. P.: Optimisation Techniques for Groundwater Management, PhD Thesis, University of Technology, Sydney (unpublished), 551 pp., 2000.

Middlemis, H., Merrick, N. P., and Ross, J. B.: Groundwater Flow Modelling Guideline, Aquaterra Consulting Pty Ltd, Consultancy Report, Perth, November 2000.

Mook, W. G. and van der Plicht, J.: Reporting ${ }^{14} \mathrm{C}$ activities and concentrations, Radiocarbon, 41, 227-239, 1999.

Moya, C. E., Raiber, M., Taulis, M., and Cox, M. E.: Using environmental isotopes and dissolved methane concentrations to constrain hydrochemical processes and inter-aquifer mixing in the Galilee and Eromanga Basins, Great Artesian Basin, Australia, J. Hydrol., 539, 304-318, 2016.

NSW Pinneena Groundwater Database: NSW Government DPI Water, available at: http://allwaterdata.water.nsw.gov.au/water.stm, last access: 19 May 2017.

Parkhurst, D. and Appelo, C.: User's guide to PHREEQC - a computer program for speciation, batch-reaction, one dimensional transport, and inverse geochemical calculations, USGS Water Resources Investigations Report, No. 994259, 1999.

Parkhurst, D. L. and Charlton, S. R.: NetpathXL - An Excel interface to the program NETPATH, USGS Techniques and Methods, 6-A26, 2008.

Phillips, F. M.: Chlorine-36, in: Environmental Tracers in Subsurface Hydrology, edited by: Cook, P. and Herczeg, A. L., 299-348, 2000.

Plummer, L. N. and Glynn, P. D.: Radiocarbon dating in groundwater systems, in: Isotope methods for dating old groundwater, Vienna, International Atomic Energy Agency, 33-89, STI/PUB/1587, 2013.

Powell, J. and Scott, F.: A representative irrigation farming system in the Lower Namoi Valley of NSW: an economic analysis, Economic Research Report No. 46, Industry and Investment NSW, 63 pp., 2011.
Puls, R. W. and Barcelona, M. J.: Low-flow (minimal drawdown) groundwater sampling procedures, EPA/540/S-95/504, 10 pp., 1996.

Radke, B., Ferguson, J., Cresswell, R. G., Ransley, T. R., and Habermehl, M. A.: Hydrochemistry ad implied hydrodynamics of the Cadna-owie-Hooray Aquifer Great Artesian Basin, Bureau of Rural Sciences, Canberra, 2000.

Raiber, M., Webb, J. A., Cendón, D. I., White, P. A., and Jacobsen, G. E.: Environmental isotopes meet 3D geological modelling: Conceptualising recharge and structurally-controlled aquifer connectivity in the basalt plains of south-western Victoria, Australia, J. Hydrol., 527, 262-280, 2015.

Rawling, G. C. and Newton, B. T.: Quantity and location of groundwater recharge in the Sacramento Mountains, south-central New Mexico (USA), and their relation to the adjacent Roswell Artesian Basin, Hydrogeol. J., 24, 757-786, 2016.

Reilly, T. E. and Harbaugh, A. W.: Guidelines for Evaluating Ground-Water Flow Models, USGS Scientific Investigations Report 2004-5038, available at: https://pubs.usgs.gov/sir/2004/ 5038/PDF.htm (last access: 10 October 2017), 2004.

Robertson, W. D. and Cherry, J. A.: Tritium as an indicator of recharge and dispersion in a groundwater system in Central Ontario, Water Resour. Res., 25, 1097-1109, 1989.

Salameh, E. and Tarawneh, A.: Assessing the imapcts of uncontrolled artesian flows on the management of groundwater resources in the Jordan Valley, Environ. Earth Sci., 76, 291, https://doi.org/10/1007/s12665-017-6610-0, 2017.

Scanlon, B. R., Healy, R. W., and Cook, P. G.: Choosing appropriate techniques for quantifying groundwater recharge, Hydrogeol. J., 10, 18-39, 2002.

Schilling, K. E., Jacobsen, P. J., Libra, R. D., Gannon, J. M., Langel, R. J., and Peate, D. W.: Estimating groundwater age in the Cambrian-Ordovician aquifer in Iowa: implications for biofuel production and other water uses, Environ. Earth Sci., 76, https://doi.org/10/1007/s12665-016-6321-y, 2017.

Sharma, P., Kuhik, P. W., Fehn, U., Gove, H. E., Nishiizumi, K., and Elmore, D.: Development of $36 \mathrm{Cl}$ standard for AMS, Nucl. Instr. Meth. B., 52, 410-415, 1990.

Short, M. A., de Caritat, P., and McPhail, D. C.: Continental-scale variation in chloride/bromide ratios of wet deposition, Sci. Tot. Environ., 574, 1533-1543, 2017.

Stone, J. O., Allan, G. L., Fifield, L. K., and Cresswell, R. G.: Cosmogenic chlorine-36 from calcium spallation, Geochim. Cosmochim. Ac., 60, 679-692, 1996.

Smithson, A.: Lower Namoi Groundwater Source: Groundwater Management Area 001, Groundwater Status Report 2008, NSW Department of Water and Energy, Sydney, 2009.

Tadros, N. Z.: The Gunnedah Basin, New South Wales, Vol. 12, Department of Mineral Resources, Coal and Petroleum Geology Branch, Sydney, 1993.

Tadros, C. V., Hughes, C. E., Crawford, J., Hollins, S. E., and Chisari, R.: Tritium in Australian precipitation: A 50 year record, J. Hydrol., 513, 262-273, 2014.

Tosaki, Y., Tase, N., Massmann, G., Nagashima, Y., Seki, R., Takahashi, T., Sasa, K., Sueki, K., Matsuhiro, T., Miura, T., and Bessho, K.: Application of ${ }^{36} \mathrm{Cl}$ as a dating tool for modern groundwater, Nucl. Instrum. Meth. B, 259, 479-485, 2007. 
Wilcken, K. M., Fink, D., Hotchkis, M. A. C., Garton, D., Button, D., Mann, M., Kitchen, R., Hauser, T., and O'Connor, A.: Accelerator Mass Spectrometry on SIRIUS: New 6 MV spectrometer at ANSTO, Nucl. Instrum. Meth. B, 406, 278-282, https://doi.org/10.1016/j.nimb.2017.01.003, 2017.

Williams, R. M., Merrick, N. P., and Ross, J. B.: Natural and induced recharge in the Lower Namoi Valley, New South Wales, in: Groundwater Recharge, edited by: Sharma, M. L., Proceedings of the Symposium on Groundwater Recharge, 239-253, 1989.
Zhang, L., Walker, G. R., and Dawes, W. R.: Water balance modelling: concepts and applications, in: Regional Water and Soil Assessment for Managing Sustainable Agriculture in China and Australia, edited by: McVicar, T. R., Rui, L., Walker, J., Fitzpatrick, R. W., and Changming, L., ACIAR Monograph No. 84, 31-47, 2002. 